\title{
Surge Protection in Low-Voltage AC Power Circuits - An Anthology Part 1 - Annotated Bibliography
}

Francois D. Martzloff U.S. DEPARTMENT OF COMMERCE Technolugy Administration Electronics and Electrical Engineering Laboratory Electricity Division

National Institute of Standards and Technology

Gaithersburg, MD 20899

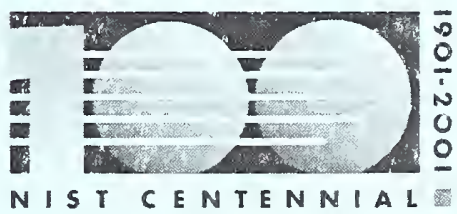





\section{Surge Protection in Low-Voltage AC Power Circuits - An Anthology Part 1 - Annotated Bibliography}

François D. Martzloff U.S. DEPARTMENT OF COMMERCE Technology Admınıstratıon Electronics and Electrical Engıneerıng Laboratory Electricity Division National Institute of Standards and Technology

Gaithersburg, MD 20899

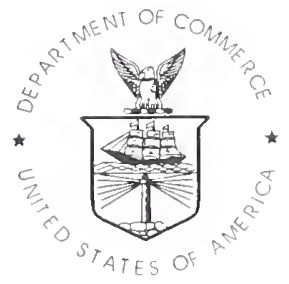

U.S. DEPARTMENT OF COMMERCE Donald L. Evans, Secretary

TECHNOLOGY ADMINISTRATION

Phillip J. Bond, Under Secretary for Technology

NATIONAL INSTITUTE OF STANDARDS AND TECHNOLOGY

Arden L. Bement, Jr., Director 


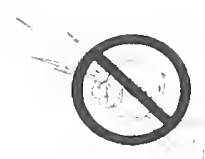

- ii - 


\section{FOREWORD}

This is the first part of a multi-part anthology, offered to promote better understanding of surge protection techniques through a historical perspective and easy access to relevant papers on the fundamental principles and application of surge-protective devices. It might also serve as a refresher to avoid reinventing surge-protective devices or techniques.

This first part, Annotated Bibliography, provides a list of papers, standards, and textbooks written by many contributors to the development of surge protection technology. Subsequent parts of this anthology will be compiled to include reprints of the public-domain papers by the author as cited in this Bibliography. Those published after 1985 under the umbrella of NIST are in the public domain. Those written before 1985 will be reprinted in by permission of the copyright holders or with declassification of proprietary reports; these releases are gratefully acknowledged.

This bibliography is provided to give the interested reader a source of reference material with a few lines of comments on content or comments on the significance of the cited document. The compilation is divided into eight categories, as listed below. Publications relevant to more then one category are listed in each category of interest to allow browsing only through a particular category and still find the listing. The listing is arranged by alphabetical order and chronology of the lead author in each category. The following are the categories for the listing:

1. Standards relevant to surge protection

2. Development of standards - Reality checks

3. Recorded surge occurrences, surveys and staged tests

4. Propagation and coupling of surges (Experiments and numerical simulations)

5. Monitoring instruments, laboratory measurements, and test methods

6. Textbooks and tutorial reviews

7. Mitigation techniques

8. Coordination of cascaded surge-protective devices

Each of the categories 2 through 8 will be compiled in installments and issued as separate booklets. In addition to the printed booklets available from the U.S. Superintendent of Documents, this Anthology will also be available on the Web, thus opening the door for suggestions of additional entries for periodic updates of the listing. The site URL is: http://www.eeel.nist.gov/811/spd-an thology/

This bibliography was initially compiled by the author as a contribution to the IEEE "Trilogy" of the SurgeProtective Devices Committee (a set of three standards on the surge environment). This initial compilation is now complemented with additional relevant papers and reports written by the author. Undertaking a listing of "relevant papers" entails the risk of offending researchers whose papers might have been overlooked in the compilation. Sincere apologies are offered in such cases, as the omission was not a deliberate act of rejection, but an unfortunate accident in an imperfect literature search that was initially focused on the Trilogy development rather than aiming to be a comprehensive and exhaustive project. Nevertheless, the volume of this Bibliography is testimony to the contributions from all the listed authors to a data base for the Trilogy. Members of the IEEE working group that developed the Trilogy also contributed suggestions for entries in the listing. All these contributions are gratefully acknowledged.

François Martzloff

December 2001

<f.martzloff@ieee.org> 
Q

- iV - 


\section{Contents}

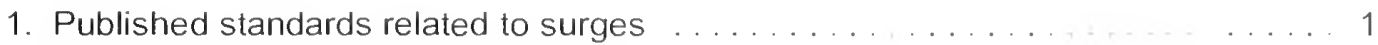

2 Development of Standards - Reality checks . . . . . . . . . . . . . . . 5

3 Recorded surge occurrences, surveys and staged tests . . . . . . . . . . 9

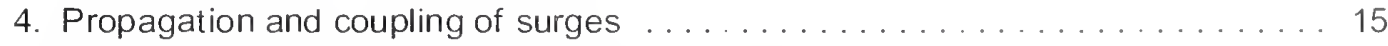

5 Monitoring instruments, laboratory measurements and test methods . . . . . . 21

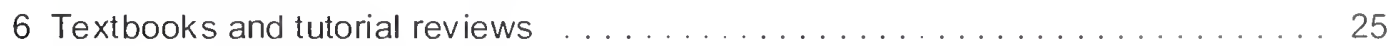

7 Mitigation techniques . . . . . . . . . . . . . . . . . . . . 29

8 Coordination of cascaded surge-protective devices $\ldots \ldots \ldots \ldots \ldots \ldots \ldots$

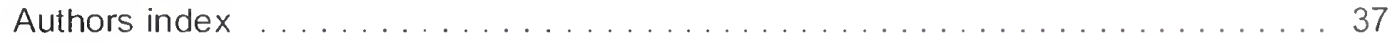


Q

- vi - 


\section{Surge Protection in Low-Voltage AC Power Circuits - An Anthology \\ Part 1 - Annotated Bibliography}

\section{Published standards related to surges}

\subsection{The IEEE C62 Series}

A bound-book collection of all ANSI and ANSI/IEEE C62 standards that were compiled periodically by the IEEE. The last such collection was published in 1995 and included all published IEEE standards applicable to Low-Voltage Surge-Protective Devices at the time of the edition. More recent updates of individual standards are listed after the following contents of the 1995 edition

C62.1-1989 (Reaff 1994) IEEE Standard for Gapped Silicon-Carbide Surge Arresters for AC Power Circuits C62.2-1987 (Reaff 1994) IEEE Guide for the Application of Gapped Silicon-Carbide Surge Arresters for AC Systems

C62.11-1993 IEEE Standard for Metal-Oxide Arresters for AC Power Circuits C62.22-1991 IEEE Guide for the Application of Metal Oxide Surge Arresters for AC Systems

C62.31-1987 (Reaff 1993) IEEE Standard Test Specifications for Gas-Tube Surge-Protective Devices

C62.32-1981 (Reaff 1993) IEEE Standard Test Specifications for Low-Voltage Air-Gap Surge-Protective Devices

C62.33-1982 (Reaff 1994) IEEE Standard Test Specifications for Varistor Surge-Protective Devices

C62.35-1987 (Reaff 1993) IEEE Standard Test Specifications for Avalanche Junction Sem iconductor Surge-

Protective Devices

C62.36-1994 IEEE Standard Test Methods for Surge Protectors Used in Low-Voltage Data, Communications, and Signaling Circuits (Now withdrawn)

C62.38-1994 IEEE Guide on Electrostatic Discharge (ESD): ESD Withstand Capability Evaluation Methods

C62.41-1991 (Reaff 1995) IEEE Recommended Practice for Surge Voltages in Low-Voltage AC Power Circuits

C62.42-1992

IEEE Guide for the Application of Gas Tube Arrester Low-Voltage Surge-Protective Devices

C62.45-1992 IEEE Guide on Surge Testing for Equipment Connected to Low-Voltage AC Power Circuits

C62.47-1992 (Reaff 1997) IEEE Guide on Electrostatic Discharge (ESD): Characterization of the ESD

Environment

C62.92.x

(A series of IEEE Guides on neutral grounding practices)

\subsection{Additional C62 Standards}

Additional C62 Standards, or major revisions published since the 1995 collection include:

C62.11-1999

C62.22-1997

C62.22.1-1996

C62.34-1996

C62.37-1996

C62.37.1-2000

C62.43-1999

C62.48-1995

C62.62-2000

C62.64-1997
IEEE Standard for Metal-Oxide Surge Arresters for Alternating Current Power Circuits (>1kV) IEEE Guide for Application of Metal-Oxide Surge Arresters for Alternating-Current Systems IEEE Guide for the Connection of Surge Arresters to Protect Insulated, Shielded Electric Power Cable Systems

IEEE Standard for Performance of Low-Voltage Surge Protective Devices (Secondary Arresters) IEEE Standard Test Specifications for Thyristor Diode Surge Protective Devices

IEEE Guide for the Application of Thyristor Surge Protective Devices

IEEE Guide for the Application of Surge Protectors Used in Low-Voltage (Equal to or less than 1000 Vrms or 1200 Vdc) Data, Communications and Signaling Circuits

IEEE Guide on Interactions Between Power System Disturbances and Surge-Protective Devices

IEEE Standard Test Specifications for Surge Protective Devices for Low Voltage AC Power Circuits

IEEE Standard Specifications for Surge Protectors Used in Low-Voltage Data, Communications, and Signaling Circuits

\subsection{Other Standards}

[1] The IEEE SPD "Trilogy" - Pending approval by the IEEE Standards Board expected in early 2002, includes three documents:

- C62.41.1 Guide on the surge environment in low-voltage ac power circuits

- C62.41.2 Recommended practice on characterization of surges in low-voltage ac power circuits

- C62.45 Recommended practice on surge testing for equipment connected to low-voltage ac power circuits 
[2] ANSI C2-1999 National Electrical Safety Code

- Rules for the protection of persons during installation, operation and maintenance of power and communications lines and equipment for utilities and for systems under the control of qualified persons.

- For building utilization wiring, refer to ANSI/NFPA 70 (National Electrical Code).

- 257 pages, 77 reference documents

[3] ANSI C84.1-1989 American National Standard for Electric Power Systems and Equipment Voltage Ratings $(60 \mathrm{~Hz})$. (Reaffirmed 1995).

- Defines steady-state limits of system voltages for the United States.

- Addresses only steady-state voltages or short-term departures from nominal conditions.

- Provides list of related standards.

[4] ANSI/NFPA-70-1999 National Electrical Code.

- A fundamental document providing minimum requirements for safe installation practices (USA)

- A companion handbook provides explanations for application of the code.

- Specifies minimum requirements for safety, not necessarily optimum surge protection.

- Allows connection of SPDs between any pair of conductors.

- Updated every three years.

[5] IEC Muttilingual Dictionary of Electricity. The Institute of Electrical and Electronic Engineers, 1983.

- A conversion of parts of the IEC International Electrotechnical Vocabulary (IEV) into a dictionary

[6] IEC 60060-2 (1994) High voltage test techniques - Part 2: Measuring systems

- Defines parameters of impulse waveforms.

[7] IEC 60364-4-442 (1999) Electrical installation of buildings - Part 4: Protection for safety - Chapter 44: Protection against overvoltages - Section 442: Protection of low-voltage installations against temporary overvoltages and faults between high-voltage systems and earth.

- Earthing systems and arrangements in transformer substations.

- Earthing arrangements and earthing systems in low-voltage installations.

- Stress voltages in cases of lost neutral (TN and TT), accidental earthing (IT), and line-to neutral short.

[8] IEC 664 (1980) Insulation coordination within low-voltage systems including clearances and creepage distances for equipment.

- Superseded, but significant historical document. See IEC 60664 below.

- Introduced the staircase concept of surge voltage reduction.

[9] IEC 60664-1 (2002) Insulation coordination within low-voltage systems Part 1: Principles, requirements and tests.

- Major revision and update of IEC 664 (above)

- No longer shows a descending staircase of voltages.

- Does not discuss surge source impedance considerations as it is concerned with insulation withstand.

[10] IEC 61000-2-5 (1995) Electromagnetic Compatibility - Part 2: Environment - Section 5: - Classification of electro-magnetic environments

- Basic EMC publication (Technical Report)

- Not a test or performance specification, but a guide to what levels of disturbances might be expected

- Proposes and arrangement with five classes of locations and corresponding characterized by levels.

[11] IEC 61000-4-4 (1995) Electromagnetic Compatibility - Part 4: Testing and measurement techniques - Section 4: Electrical fast transient/burst immunity tests.

- Specifies interference immunity test with bursts of fast-transient pulses applied to EUT in "common mode" by a coupling clamp or in selective mode by capacitor coupling.

[12] IEC 61000-4-5 (2001) Electromagnetic Compatibility - Part 4: Testing and measurement techniques - Section 5: Surge immunity test. Consolidated Edition.

- Specifies the Combination Wave (1.2/50 -8/20) only for power circuits (no mention of Ring Wave)

- Line-to-earth test voltage levels are twice the levels specified for line-to-line.

[13] IEC/TS 61312-3 (2000) Protection against LEMP; Part 3: Requirements of Surge Protective Devices.

- Presents the IEC TC81 perception of "requirements" for service-entrance SPDs.

- Approved according to the IEC operating procedures, but with only $68 \%$ of the votes. 
[14] IEC 61643-1 (2002) Surge protective devices connected to low-voltage power distribution systems - Part 1: Performance requirements and testing methods

- Defines three classes of tests, I, II, and III with specific energy and charge stress levels.

- Does not relate the test levels to the location of application.

[15] IEC 62066 (To be published 2002) General basic information regarding surge overvoltages and surge protection in low-voltage a.c. power circuits.

- A tutorial technical report describing the origins, propagation, and mitigation of surges.

- Bibliography with 58 citations, sim ilar to the present bibliography.

[16] IEEE C37.90.1-1989 IEEE Standard Surge Withstand Capability (SWC) Tests for Protective Relays and Relays Systems [Note: Revision in progress as PC37.90.1 - 2000]

- A document developed for the environment of high-voltage substation equipment. Its fast transient requirement, with a rise time of less than $10 \mathrm{~ns}$, is similar to the IEC EFT burst requirement.

- Calls for a $1 \mathrm{MHz}$ to $1.5 \mathrm{MHz}$ ring wave and a $4 \mathrm{kV}$ to $5 \mathrm{kV}$ peak impulse, < $10 \mathrm{~ns}$ rise time.

- 14 references

[17] IEEE Std 4-1995 IEEE Standard Techniques for High-Voltage Testing

- Defines impulse parameters.

[18] IEEE Std 446-1995 IEEE Recommended Practice for Emergency and Standard Power Systems for Industrial and Commercial Applications

- The earliest publication of the "CBEMA Curve" (updated as "ITIC Curve") occurred in the 1980 edition of this standard.

[19] IEEE Std 518-1982 (Reaff 1996), IEEE Guide for the Installation of Electrical Equipment to Minimize Noise Inputs to Controllers from External Sources.

- Discusses the sources of electrical noise; provides an example of the "showering arc" leading to the EFT concept

- Provides guidance on noise reduction (not suppression) and installation practices.

[20] IEEE Std 1100-1999, IEEE Recommended Practice for Powering and Grounding Electronic Equipment

- Recommended engineering principles and practices for powering and grounding electronic equipment in commercial and industrial applications

- 400 pages, 120 bibliographic citations

[21] IEEE Std 1159-1995 IEEE Recommended Practice for Monitoring Electric Power Quality

- Provides definitions of power systems disturbances.

- Makes recommendations on deployment of surge monitoring instruments.

- Makes recommendations on interpretation of power quality surveys.

[22] UL Std 93-1975, Standard for Safety - Ground Fault Circuit Interrupters.

- First proposal to industry of what became the $100 \mathrm{kHz}$ Ring Wave.

[23] UL Std 1449 Standard for Safety -- Transient Voltage Surge Suppressors, Underwriters Laboratories.

- First Edition: 1985; Second Edition, 1996

- The second edition which became effective in 1998, features a new set of failure mode tests.

- Specifies safety aspects of suppressor design, with some performance implications.

- Requires citation of limiting voltage level, from a tabulation of values startıng at $330 \mathrm{~V}$. 


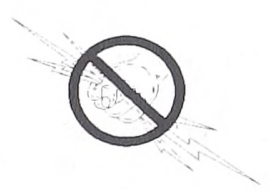

Page 4 


\section{Development of Standards - Reality checks}

[24] ANDERSON, L.M. and BOWES, K.B., "The Effects of Power-line Disturbances on Consumer Electronic Equipment," IEEE Transactions PWRD-5, No.2, April 1990.

- Experimental study of the immunity of typical electronic equipment to sags and surges

- Surges applied were not the ANSI C62.41, but a $100 \mu$ s or $300 \mu$ s pulse, presumably open-circuit voltage.

- Surges of $1000 \mathrm{~V}$ (open-circuit voltage of generator) did not cause any failure of PCs

[25] BACHL, H., MARTZLOFF, F.D. and NASTASI, D., "Using Incandescent Lamp Failure Levels for Assessment of the Surge Environment," Proceedings, $12^{\text {th }}$ International Zürich Symposium on Electromagnetic Compatibility, 1997.

- Shows failure mechanisms and levels, by electrical measurements, with high-speed video recording.

- $120-\mathrm{V}$ lamps can fail in the range of $800 \mathrm{~V}$ to $1200 \mathrm{~V}$, depending on waveshape and phase angle.

- Makes the point that surges are unlikely to occur frequently at levels above the failure level of lamps.

- 5 references

[26] BARTKOWIAK, M., COMBER, M.G., and MAHAN, G.D., "Failure Modes and Energy Absorption Capability of ZnO Varistors," IEEE Transactions PWRD-14, January 1999.

- Simulation of varistor behavior under current pulses of various magnitudes and duration.

- Comparison with experimental results.

- Demonstrates that energy-handling capability is not a constant, but depends on intensity and duration.

- 14 references, 1 discussion

[27] FENIMORE, C. and MARTZLOFF, F.D., "Incompatibility Between the 100/1300 Surge Test and Varistor Failure Rates." Proceedings, $9^{\text {h }}$ International Zürich Symposium on Electromagnetic Compatibility, 1991

- Numerical computations of the energy deposition associated with a proposed IEC standard indicate that massive failure of ubiquitous metal-oxide varistors should occur - but they do not.

- The proposed test was eventually removed from the menu of IEC EMC test methods.

- 10 references

[28] FENIMORE, C. and MARTZLOFF, F.D., "Validating Surge Test Standards by Field Experience: High-Energy Tests and Varistor Performance," IEEE Transactions IA-28 No.6, December 1992. (First publication in Conference Record, IEEE/IAS Annual Meeting, Oct. 1990).

- Computer modeling of the resulting current and energy deposition into typical varistors subjected to the proposed $10 / 1300 \mu$ s waveform.

- Yields a prediction of failure for the small varistors and survival for the larger varistors.

- Because small varistors do not fail in the field at the rate that is predicted by the model, the conclusion is that stresses associated with this proposed waveform make it unrealistic.

- 15 references

[29] GOEDDE, G.L., KOJOVIC, Lj.A., and WOODWORTH, J.J., "Surge Arrester Characteristics that Provide Reliable Overvoltage Protection in Distribution and Low-Voltage Systems," Proceedings, IEEE-PSE Summer Meeting, Seattle WA, July 2000.

- Describes field experience of arresters designed in accordance with IEEE Std C62.11-1999

- Concludes that tests with a 10/350 $\mu$ s waveform are not necessary.

- 11 references

[30] KEY, T.S., MARTZLOFF, F.D., WITT, R., MAY, J., and BLACK, S., "Developing a Consumer-Oriented Guide on Surge Protection," Proceedings, PQA'97 North America, 1997.

- Progress report on the development of a tutorial on surge protection.

- Presents the need for "intersystem bonding" at the entrance of power and communications utilities

- Brief discussion of the need for surge reference equalizers.

- 6 references

[31] MACIELA, F., "Energetic Design and EDF Distribution Network Experience of MV Metal Oxide Surge

Arresters," CIGRE SC33.95 (1995 Colloquium).

- Field experience of EDF on 700000 arresters.

- Failure rate lower (1/4) than calculated in [44] Rousseau, 1989 (CIRED). 
[32] MANSOOR, A., MARTZLOFF, F.D., and NASTASI, D., "Applying Reality Checks to Standards on the Surge Environment," Proceedings, $23^{\text {rd }}$ International Conference on Lightning Protection, Florence, 1996.

- Shrinking surge recordings vs, proliferation of SPDs.

- Applying equipment failure rates to assess the surge environment.

- Limits to pushing surges into branch circuits.

- 19 references

[33] MANSOOR, A. and MARTZLOFF, F.D., "Driving High Surge Currents into Long Cables: More Begets Less," IEEE Transactions PWRD-12, No.3, July 1997.

- Measurements and modeling, validating each other, show the physical impossibility for large surge currents to propagate very far into the branch circuits of a building, because flashover will occur at the service entrance.

- Demonstrates the importance of considering the maximum rate of rise (early in the surge) rather than the peak value and overall rise time.

- 13 references

[34] MANSOOR, A. and MARTZLOFF, F.D., "The Effect of Neutral Earthing Practices on Lightning Current Dispersion in a Low-Voltage Installation," IEEE Transactions PWRD-13, July 1998.

- Compares the TN and TT for dispersion of lightning current in several scenarios.

- Shows the need for careful review of grounding practices in effect at service entrances.

- Questions the applicability of high amplitude, long duration requirement for service entrance SPDs.

- 20 references

[35] MANSOOR, A. and MARTZLOFF, F.D., "The Dilemma of Surge Protection vs. Overvoltage Scenarios: Implications for Low-Voltage Surge-Protective Devices," Proceedings, 8th International Conference on Harmonics and Power Quality, Oct 14-16, 1998, Athens, Greece.

- Three examples of temporary overvoltage conditions that can produce failure of SPDs.

- The significance of available fault current and the need for more explicit standards.

- 17 references

[36] MANSOOR, A., MARTZLOFF, F.D., and PHIPPS, K., "The Fallacy of Monitoring Surge Voltages: SPDs and PCs Galore!" Proceedings, EPRI PQA'99 Conference, May 1999

- Experimental measurements of effective mitigation by multiple SPDs.

- Numerical simulation of the effect of proliferating SPDs and PCs.

- Calls for an industry-wide reassessment of surge monitoring parameters.

- 20 references

[37] MARTZLOFF, F.D. and FISHER, F.A., "Transient Control Level Philosophy and Implementation," Part 1: The Reasoning Behind the Philosophy," Proceedings, $2^{\text {nd }}$ Symposium on Electromagnetic Compatibility, Montreux, 1977.

- Presents the concept of testing low-voltage equipment patterned on the high-voltage BIL concept

- Techniques and equipment for making TCL tests.

- 10 references

[38] MARTZLOFF, F.D., "Varistor Versus Environment: Winning the Rematch," IEEE Transactions PWRD-1, No. 2, April 1986.

- Staged test of capacitor switching on remote MV side produces ring waves on low-voltage load.

- Coordination between $3 \mathrm{kV}$ and $480 \mathrm{~V}$ varistor-based SPDs.

- 5 references, 1 discussion

[39] MARTZLOFF, F.D., "Testing Varistors Against the VDE 0160 Standard," Proceedings, Open Forum on Surge Protection Application, NISTIR-4654, August 1991.

- Reports tests performed with a prototype 100/1300 surge generator, resulting in failure of the ubiquitous $20-\mathrm{mm}$ diameter varistors, hence demonstrating that the proposed standard is unrealistic.

- 9 references

[40] MARTZLOFF, F.D. and PELLEGRINI, G., "Real, Realistic Ring Waves for Surge Testing," Proceedings, $9^{\text {th }}$ International Zürich Symposium on Electromagnetic Compatibility, 1991.

- Reports measurements on the propagation of oscillatory waves in typical low-voltage circuits, as opposed to the unidirectional waves initially defines for high-voltage power systems.

- Shows how impinging unidirectional surges can produce oscillatory waves responses.

- 17 references 
[41] MARTZLOFF, F. D.. "On the Dispersion of Lightning Current after a Direct Flash to a Building," Proceedings, $25^{\text {th }}$ International Conference on Lightning Protection, Rhodes, 2000.

- Computer modeling of the current dispersion among available paths to ground.

- Comparis on between proposed SPD ratings based on computer modeling and field experience.

- 9 references

[42] MEISSEN, W., "Überspannungen in Niederspannungsnetzen" [Overvoltages in low-voltage networks], ETZ Bd. 104, 1983.

- The seminal paper proposing a long waveform with extremely high energy-deposition capability, leading to the development of German Standard DIN 0160.

[43] RICHMAN, P., "New Fast-Transient Test Standards Inadvertently Permit Overstressing by as much as 600 Percent," EMC Test and Design, Vol.2, No.5, Sept/Oct 1991

- Points out ambiguities in the test procedures.

[44] ROUSSEAU, A., "Requirements for Rating of MV Zinc Oxide Surge Arresters on EDF Distribution Networks," CIRED 1989.

- Design of ZnO MV arresters based on statistics of lightning current magnitude and tail.

- Sharing of current between many arresters as well as number of lightning strike per year and per $\mathrm{km}$ of overhead line are used in calculations.

- Design based on an energy requirement converted in lab into a 4/10 standard waveshape

- 13 references

[45] SMITH, S.B. and STANDLER, R.B., "The Effects of Surges on Electronic Appliances," IEEE Transactions PWRD-7, No.3, July 1992.

- Clocks, TV receivers, and switching power supplies were subjected to surges from $0.5 \mathrm{kV}$ to $6 \mathrm{kV}$.

- The switching power supplies and television receivers were damaged with surges from $4 \mathrm{kV}$ to $6 \mathrm{kV}$.

- Three of five models of digital clocks were upset with surges from $1.6 \mathrm{kV}$ to $6 \mathrm{kV}$.

- The conventional wisdom that electronic appliances are easily damaged by surges with a peak voltage of a few kilovolts greatly exaggerates the effect of surges on modern consumer appliances.

- 15 references

[46] STANDLER, R.B., "Development of a Performance Standard for Surge Arresters and Suppressors," Proceedings, IEEE 1991 International Symposium on Electromagnetic Compatibility.

- Some critical issues in the development of a performance standard for surge arresters and suppressors for use on low-voltage mains are discussed.

- A series of electrical tests to determine the safety and adequacy of surge protective devices is described.

- 4 references

[47] STANDLER, R.B., "Calculation of Energy in Transient Overvoltages," Proceedings, IEEE EMC Symposium, 1989.

- Shows that using the integral of $V^{2} / 50 \Omega$. dt to compute energy in a surge is invalid.

- A quantitative error analysis is presented that uses an artificial AC line network to simulate a long branch circuit and to give the impedance of the $\mathrm{AC}$ line as a function of frequency.

- A method for measuring energy dissipated in a varistor is advocated for use in future experiments.

- 18 references

[48] STANDLER, R.B., "Standards for Surge-protective Devices for Connection to the Low-voltage Ac Supply Mains in the USA." Proceedings. Lightning Protection 92 - Buildings, Structures and Electronic Equipment Conference and Exhibition, 1992.

- A review major standards in the USA for low-voltage AC power surge-protective devices prepared for presentation at a European based forum.

- Since it is clear that international standards are greatly preferable for both manufacturers and users, the US position [in 1992] on the IEC SC37A drafts is also briefly reviewed.

- 9 references

[49] VANCE, E.F., NANEVICZ, J.E., and GRAF, W., "Unification of Electromagnetic Specifications and Standards," Defense Nuclear Agency Report DNA 5433F-1, Washington DC, 1980.

- Describes the need for dual capability of a test generator to adapt inherently to the impedance of the EUT, even during the surge event. 


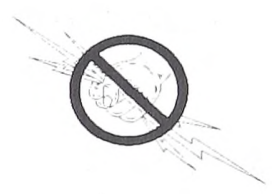

Page 8 


\section{Recorded surge occurrences, surveys, and staged tests}

[50] ACKERMANN, G., HUDASCH, M., SCHWETZ, S., and STIMPER, K., "Überspannungen in Niederspannungsanlagen" [Overvoltages in low-voltage installations], ETZ Bd. 114 (1993)

- Reports surge monitoring performed in Germany.

[51] ACKERMANN, G., SCHEIBE, K., and STIMPER, K., "Isolationgefährdende Überspannungen im Niederspannungsbereich," [Overvoltages hazardous to insulation in low-voltage systems], ETZ, Bd 118 (1997).

- Reports surge measurements in Germany that include "energy content" in Ws (watts x seconds).

- 10 references

[52] AIEE Committee Report "Switching Surges - I - Phase to Ground Switching Voltages," AlEE Transactions PAS-80, June 1961

- Comprehensive report, 1961 vintage, of the subject.

- 84 references, 10 discussions

[53] ALLEN, G.W. and SEGALL, D., "Monitoring of Computer Installation for Line Disturbances," presented at the IEEE Power Engineering Society Winter Meeting. New York, NY, Jan. 1974, Paper C74 (Conference preprint only.)

- Reports occurrence rates at computer sites, recorded with CRT memory scopes.

- Possible artifact of insufficient writing speed discussed but not appended to conference preprint. See IEEE Std C62.41.1-2002 data base for that discussion.

- 7 references

[54] ANDERSON, R.B. and ERIKSSON, A. J., "Lightning Parameters for Engineering Application," ELECTRA No.69, 1980.

- Probability of occurrence of lightning flashes.

- Peak current amplitude and waveshape parameters.

- 55 references.

[55] ASPNES, J.D., EVANS, B.W., and MERRITT, R.P., "Rural Alaska Electric Power Quality," IEEE Transactions PAS-104, No.3, March 1985.

- Survey with digital-output disturbance monitors.

- Did not consider the effect of SPDs integrated in the instrument power supply that limited observed surges

- 28 references, 2 discussions

[56] BACHMAN, L., GULLBERG, M., STRICKLER, F., and SACHS, H., "An Assessment of Shipboard Power Line Transients."Proceedings, International IEEE EMC Symposum, Aug. 1981.

- Surge recordings with storage oscilloscope and disturbance analyzers.

[57] BARKER, P.P., MANCAO, R.T., KVALTINE, D.J., and PARRISH, D.E., "Characteristics of Lightning Surges Measured at Metal-Oxide Distribution Arresters," IEEE Transactions PWRD-8, January 1993.

- Recording of 1309 lightning surges at four sites of distribution systems.

- Uses a modified MOV arrester as transducer to bring signals down to low-voltage input of recorder

- 23 references

[58] BEJLERI, M., RAKOV, V.A., UMAN, M.A., RAMBO, K.J., MATA, C.T., and FERNANDEZ, M.I., "Triggered Lightning Testing of an Airport Runway Lighting System," Proceedings, $25^{\text {th }}$ International Conference on Lightning Protection, Rhodes, September 2000.

- Injection of triggered lightning current into a runway lighting system at Camp Blanding

- Measurements of the dispersion of lightning current among ground rods and counterpoise.

- 3 references

[59] BELhOMme, R., PLAMONDON, M., NAKRA, H., DESROSIERS, D., and GAGNON, C., "Case Study on the Integration of a Non-Utility Induction Generator to the Hydro-Québec Distribution Network," IEEE Transactions PWRD-10, No.3, July 1995.

- Investigates the influence of load, capacitive compensation, machine parameters on resulting overvoltages.

- Presents results of simulation of a distribution network.

- 11 references 
[60] BERGER, K., ANDERSON, R.B., and KRÖNINGER, H., "Parameters of Lightning Flashes," ELECTRA No.41, 1975

- The seminal paper on lightning parameters.

- Statistical distribution of 10 parameters, including peak current, charge, and waveshape.

- 8 references

[61] BODLE, D.W., GHAZI, A.J., SYED, M., and WOODSIDE, R.L., Characterization of the Electrical Environment, University of Toronto Press, 1976.

- Book initially written from the communications point of view but applicable to AC power circuits.

- 124 references, 320 pages

[62] BOEHNE, E.W. and LOW, S.S., "Shunt Capacitor Energization with Vacuum Interrupters - A Possible Source of Overvoltage," IEEE Transactions, PAS-88, No. 9, Sept. 1969.

- Field tests and computer analysis for overvoltages on transformers and arresters, with corrective measures.

- 15 references, 11 discussions

[63] BULL, J.H. and NETHERCOT, M.A., "The Frequency of Occurrence and Magnitude of Short Duration Transients in Low-Voltage Supply Mains," Radio Electronic Engineer, September 1964.

- Peak-reading recordings at substations, bus-bars, and point-of use.

- 5 references

[64] CANNOVA, S.F., "Short-Time Voltage Transients in Shipboard Electrical Systems,"IEEE Transactions IA-9, No.5, Sept/Oct 1973 .

- Oscilloscope recordings and histograms.

- 18 references

[65] CHOWDHURI, P., "Estimation of Flashover Rates of Overhead Power Distribution Lines by Lightning Strokes to Nearby Ground," IEEE Transactions PWRD-4, No.3, July 1989.

- Computation of flashover rates as a function of BIL.

- 18 references, 1 discussion

[66] CIANOS, N. and PIERCE, E.T., "A Ground-Lightning Environment for Engineering Usage," Stanford Research Institute, Menlo Park, CA 94205, Aug 1972

- Comprehensive statistics on the characteristics of lightning.

- 108 references, 136 pages

[67] CUMMINS, K.L., MURPHY, M.J., BARDO, E.A., HISCOX, W.L., PYLE, R.B., and PIFER, A.E., "A Combined TOA/MDF Technology Upgrade of the U.S. National Lightning Detection Network," Journal of Geophysical Research, Vol 103 No D8, April 1998.

- Summarizes the development and upgrade of the U.S. National Lightning Detection Network.

- Provides examples of the cumulative distribution of peak current.

- 36 references

[68] DARVENIZA, M. and UMAN, M.A., "Research Into Lightning Protection of Distribution Systems - Part II, Results from Florida Field Work 1978 and 1979," IEEE Transactions PAS-103, No. 4, 1984.

- Statistics on the occurrence of lightning.

- 14 references

[69] DORR, D.S., "Point of Utilization Power Quality Study Results," IEEE Transactions IA-31 No.4, July/August 1995.

- Presents results of four years of monitoring at 112 North American locations.

- Cites relatively low rate of occurrence of surges above 500 volts, suggesting that the proliferation of SPDs can be the cause of this low incidence.

- Other Power Quality statistics include sags, swells, and outages.

- 17 references

[70] FERNANDEZ, M.I., RAMBO, K. J., STAPLETON, M.V., RAKOV, V.A., and UMAN, M.A. , "Review of Triggered Lightning Experiments Performed on a Power Distribution System at Camp Blanding, Florida, During 1996 and 1997," Proceedings, 24 International Conference on Lightning Protection, Birmingham, UK, 1998.

- Injection of triggered lightning current into several configurations at Camp Blanding.

- Review of tests reported in earlier papers and preview of forthcoming test reports.

- 3 references 
[71] FERNANDEZ, M.I., RAKOV, V.A., and UMAN, M.A., "Transient Currents and Voltages in a Power Distribution System Due to Natural Lightning," Proceedings, 24th International Conference on Lightning Protection,

Birmingham, UK, 1998

- Opportunistic natural flash events at the triggered lightning facility of Camp Blanding.

- One flash struck earth away from the line: electromagnetic coupling and injection via ground connections.

- One flash event struck the directly the overhead distribution line, equipped with MOV arresters at the time.

- 4 references

[72] GAIBROIS, G.L., MASHIKIAN, M.S., and JOHNSON, K., "Study of Lightning Current Magnitude Through Distribution Arresters," EPRI Report No. EL-1140, Sept. 1979.

- Citation of long duration current in arresters.

- 8 references

[73] GOEDBLOED, J.J., "Transients in Low-Voltage Supply Networks," IEEE Transactions EMC-29, No. 2, May 1987

- Shows rates of rise up to $30 \mathrm{kV} / \mu \mathrm{s}$, peaks exceeding $3 \mathrm{kV}$.

- Contains extensive analysis of data.

- Avoids the use of 'energy in the surge' but defines 'energy measure' based on integral of $v^{2} d t$.

- 13 references

[74] GOEDDE, G.L., DUGAN, R.C., ROWE, LD., HARTANA, R., SKLIUTAS, J., and WALLING, R., "Full Scale Lightning Surge Tests of Distribution Transformers and Secondary Systems," IEEE Transactions PWRD-7, No.3, July 1992.

- Low-side surges are known to cause failures of low voltage distribution transformers.

- Tests on low-side surges were found to consist of two basic components:

- The natural frequency of the system, responsible for corona discharge spots at secondary bushings.

- The inductive response of the system to the stroke current, responsible for transformer failures.

- 11 references

[75] GOLDSTEIN, M. and SPERANZA, P.D., "The Quality of U.S. Commercial AC Power," Intelec Conference Proceedings, 1982.

- Monitoring with Dranetz 606-3 at Bell Telephone sites.

- Statistical discussion of relative percentages of disturbances based on arbitrary thresholds.

[76] GREBE, T.E., "Application of Distribution System Capacitor Banks and Their Impact on Power Quality," IEEE Transactions IA-32, No.3, May/June 1996.

- Discussion of capacitor switching transients and magnification effects.

- Provides several examples of recordings with the "PQNode" instrument.

- Points out the need to evaluate energy considerations if MOVs are applied for mitigation.

- 6 references

[77] HAHN, G.J. and MARTZLOFF, F.D., "Surge Voltages in Residential Power Circuits," IEEE Conference Paper, Summer Power Meeting, Portland OR July 1967.

- First publication of the GE surge monitoring project, later upgraded as IEEE Transactions PAS-89, No.6, July/Aug 1970 - See listing under [86] Martzloff \& Hahn.

[78] HAIRABEDIAN, B. "A Survey of Power Line Disturbances at Typical Ibm Computer Installations in the U.S. for the Period 1988-1992." Document Number TR 21.1507, IBM Corporation, Kingston NY, June 1992.

- The survey logged 22201 monitor-days at 25 IBM computer sites.

- Frequency-distribution tables, Weibull profiles, histories of monthly events, and chronologies of vents.

- The composite results of the survey are compared with those of the 1972 and 1982 IBM surveys.

- 93 pages, 5 references

[79] HARUKI, H., SUNAGA, M., KIMATA, R., and KATOH, J., "Development of a Lightning Current Waveform Measuring System for 500 kV Overhead Transmission Lines," IEEE Transactions, PWRD-4, No. 3, July 1989

- Reports submicrosecond rise times of lightning current and differences in winter and summer lightning in Japan.

- 7 references

[80] HASLER, R. and LAGADEC, R, "Digital Measurement of Fast Transients on Power Supply Lines," Proceedings, $3^{d}$ Symposium on Electromagnetic Compatibility, Rotterdam, 1979.

- Monitoring with a digital system show ring waves and nanosecond rise times near switching devices.

- 1 reference (in German) 
[81] HUGHES, M.B. and CHAN, J.S., "Canadian National Power Quality Survey Results," Proceedings, EPRIPQA'95 Conference 1995.

- Reports results of monitoring surge occurrences (only as part of a power quality survey).

- Three-year period at 550 sites classified as industrial, commercial, and residential, each for one month.

- 8 references

[82] KEY, T.S. "Diagnosing Power Quality-Related Computer Problems," IEEE Transactions, IA-15, No. 4, July/Aug. 1979.

- Records of disturbances and general discussion.

- Early version of the computer susceptibility curve that became "The CBEMA Curve."

- 10 references

[83] LENZ, J.E., "Basic Impulse Insulation Levels of Mercury Lamp Ballasts for Outdoor Applications," Illuminating Engineering, Feb. 1964.

- Reports (in the discussion) oscilloscope recordings at pole-mounted transformers with $5.6 \mathrm{kV}$ peaks, the maximum surge recording in $120 \mathrm{~V}$ circuits found in the literature.

[84] MacGORMAN, D.R., MAIER, E.W. and RUST, W.D., "Lightning Strike Density for the Contiguous United States From Thunderstorm Duration Records," Report NUREG/CR-3759, U.S. Nuclear Regulatory Commission, 1984.

- Lightning strike density computed from aviation stations observations, presented as maps and tables.

- 16 references

[85] MARTZLOFF, F.D., "Surge Suppression in a Typical Home Wiring System," Declassified GE TIS Report 63GL97, 1963.

- Injection of surges and their propagation in a residential power system.

- Examples of suppression achieved by selenium cells before the advent of metal-oxide varistors.

- 2 references

[86] MARTZLOFF, F.D. and HAHN, G.J., "Surge Voltages in Residential and Industrial Power Circuits," IEEE Transactions PAS-89, No. 6, July/August 1970.

- Oscilloscope recordings show ring waves; peak detector recordings yield statistics.

- Documents the anecdotal story of clock motor failure rates.

- 9 references

[87] MARTZLOFF, F.D., "Transient Overvoltages in Secondary Systems," Unclassified GE TIS Report 81CRD121, 1981

- Capsule summary of data collected in the survey over the period of 1963-1970.

- Large-size, first generation reproductions of original oscillograms contributed to IEEE Std C62.41.

- 6 references

[88] MARTZLOFF, F.D., "Varistor Versus Environment: Winning the Rematch," IEEE Transactions PWRD-1, No. 2, April 1986.

- Staged test of capacitor switching on remote MV side produces ring waves on low-voltage load.

- Coordination between $3 \mathrm{kV}$ and $480 \mathrm{~V}$ varistor-based SPDs.

- 5 references, 1 discussion

[89] McEACHERN, A., Handbook of Power Signatures. Foster City, CA: Basic Measuring Instruments Pub., 1989.

- Reports generic types of disturbances.

- Procedures on conducting a site survey.

[90] MEISSEN, W., "Überspannungen in Niederspannungsnetzen" [Overvoltages in low-voltage networks], ETZ Bd. 104, 1983.

- The seminal paper proposing long waveform with extremely high energy-deposition capability (leading to the development of German Standard DIN 0160, but no longer acknowledged by the IEC TC77).

- Documents the effects of fuse blowing in industrial environments

[91] MELLIT, B., "Transient Voltages Generated by Inductive Switching in Control Circuits," Proceedings IEE, vol. 121, No. 7, July 1974 .

- Shows field and laboratory recordings of bursts such as those involved in the IEC EFT specifications.

- 11 references 
[92] MINEGISHI, S., ECHIGO, H., and SATO, R., "Frequency Spectra of the Arc Current Due to Opening Electric Contacts in Air," IEEE Transactions, EMC-31, No. 4, Nov. 1989.

- Reports measurement in megahertz range of contact opening sequences.

- 11 references

[93] ODENBERG, R. and BRASKICH, B.J., "Measurements of Voltages and Current Surges on the AC Power Line in Computer and Industrial Environments," IEEE Transactions, PAS-104, No. 10, Oct. 1985.

- Reports mostly long-duration surges (1000 $\mu \mathrm{s})$.

- 5 references, 2 discussions

[94] ORVILLE, R.E., HENDERSON, R.W., and PYLE, R.B., "Lightning Flash Characteristics: 1987, Interim Report," EL-6413, Electric Power Research Institute, August 1989.

- Statistics and maps of lightning ground flashes for Eastern United States.

- 13 references

[95] PELLETIN, J. and LEROY, J., "Experimentation races tameness - Résultats de la campagne d'investigations 1973. Enregistrement de surtensions atmosphériques affectant les postes MT/BT et les dérivations d'abonnès d'artères de distribution rurales - Analyse statistique des enregistrements. [Experiments on sample networks Results from the 1973 investigation. -EDF - DER - M15-375 - May 1974. (In French)

- Recordings of atmospheric overvoltages on MVILV stations and rural distribution lines.

- Statistical analysis of the recordings.

[96] PFEIFFER, W, and SCHEUERER, F., "Überspannungen in Niederspannungsnetzen" [Overvoltages in lowvoltage networks], ETZ Bd.113 (1992). (In German)

- Reports measurements conducted in Germany in the late eighties.

[97] POPOLANSKY, F., PROCHAKZKA, F., and SCHLAMP, M., "Frequency Distribution of Peak Values of Lightning Overvoltages in a Rural Low-voltage Network," Proceedings, $21^{\text {th }}$ International Conference on Lightning Protection, Berlin, 1992.

- Statistics of the recording of lightning-induced surges in an overhead line.

[98] RAKOV, V.A. and UMAN, M.A., "On the Duration of Time Intervals Between Lightning Return Stokes," Proceedings, $22^{\text {nd }}$ International Conference on Lightning Protection, Budapest, 1994.

- Electric field measurements and TV records of multiple strokes.

- Time intervals between two stroke can be less than one millisecond.

- 25 references

[99] RAKOV, V.A., UMAN, M.A., FERNANDEZ, M.I., THOTTAPPILLIL, R., EYBERT-BERARD, A., BERLANDIS, J.P., RACHIDI, F., RUBINSTEIN, M., GUERRIERI, S., and NUCCI, C.A., "Observed Electromagnetic Environment Close to the Lightning Channel," Proceedings, $23^{\text {th }}$ International Conference on Lightning Protection, Florence, Italy, 1996.

- Measurements at Camp Blanding of electric and magnetic fields at distances of tens to hundreds of meters from point of strike.

- Comparisons with data from Kennedy Space Center and Fort McClelland.

- 9 references

[100] RHOADES, W.T., "Characteristics of Unusual Power Mains Transients," Proceedings, 6" Symposium on Electromagnetic Compatibility, Zürich, 1985.

- Transients associated with UPS operation and CRT flashover.

- 5 references

[101] SABIN, D.D., "An Assessment of Distribution System Power Quality," EPRI Report TR-106294-V2, 1996.

- Comprehensive statistical data base of power quality measurements collected during the EPRI Distribution Power Quality (DPQ) Project.

- 15 references

[102] SPERANZA, P.D., "A Look at the Quality of AC Power Serving the Bell System," Bell Lab Record, July/August 1982.

- Generic report of recordings and statistical discussion. 
[103] STANDLER, R.B., "Transients on the Mains in a Residential Environment," IEEE Transactions EMC-31, No.2, May1989.

- Measurement by digital oscilloscope of transients on the single-phase $120 \mathrm{~V}$ mains of a residential environment.

- Waveforms are shown for transient overvoltages on the mains caused by three nearby lightning strikes and one unknown source. Statistical summaries are presented for all naturally occurring transients.

- Waveforms are presented for the transient caused by switching on various loads, resulting in rates of rise ranging from $6 \mathrm{kV} / \mu \mathrm{s}$ to $17 \mathrm{kV} / \mu \mathrm{s}$.

- 6 references

[104] TRUEBLOOD, H.M. and SUNDE, E.D., "Lightning Observations in Buried Cables," Bell System Technical Journal, XVIII, April 1949.

- Presents the concept of "stroke factor".

[105] WERNSTRÖM, H., BROMS, M., and BOBERG, S., "Transient Overvoltages on AC Power Supply Systems in Swedish Industry," Report FOA E 30002-E2, Foorsvarets Forskningsanstaldt, Huvudavdelning , Sweden, 1984.

- Shows rise times in the range of $60 \mathrm{~ns}$ to $600 \mathrm{~ns}$.

- Contains a graph of number of occurrences versus peaks.

- 12 references

-0-0-0-0-0-0-0-0- 


\section{Propagation and coupling of surges (Experiments and numerical simulations)}

[106] ALTMAIER, H., PELZ, D., and SCHEIBE, K., "Computer Simulation of Surge Voltage Protection in Low-

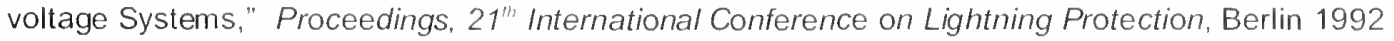

- Presents simulations of direct lightning strikes to the building for TN, TT, and IT power distribution systems.

- Makes the statement "Coordination must be done on a basis of lightning currents with the 10/350 waveform."

- 31 references

[107] BIRKL, J., HASSE, P., and ZAHLMANN, P., "Investigation of the Interaction of Lightning Currents with Low-

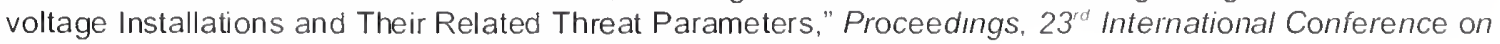
Lightning Protection, Firenze, 1996.

- Considers first stroke, subsequent stroke, and continuing current.

- Impact on surge arresters

- 5 references

[108] CIGRE Study Committee 33, WG 33.01 "Guide to Procedures for Estimating the Lightning Performance of Transmission Lines," Electra Brochure, 1992.

[109] CROUCH, K.E. and MARTZLOFF, F.D., "Lightning Protection of Residential AC Wiring," Declassified GE Memo Report MOR-78-095, 1978.

- Effect of large currents flowing in the neutral/grounding conductor of the service drop to a building.

- A unidirectional $8 / 20 \mu$ s current flowing only in the grounding conductors induces oscillatory transients in the differential mode. (Test results contributed to the data base of IEEE Std C62.41.)

- 5 references

[110] DUGAN, R.B. and SMITH, S.D., "Low-voltage-side Current Surge Phenomena in Single-phase Distribution Transformer Sysiems," Proceedings, IEEE T\&D Conference, 1986.

- Describes the scenario of a lightning strike to the service drop and resulting surges in the transformer.

- Simulations show the effects of placing surge arresters at the transformer secondary terminals.

- 7 references

[111] DUGAN, R.B., "Conduction of Lightning Stroke Currents from the Utility System to Load Devices,"

Proceedings, First International Power Quality Conference, October 1989.

- Coupling of surges between grounding conductors, etc., and the line conductors during lightning currents.

- Describes solutions.

- 4 references

[112] DUGAN, R.B., KERSHAW, S.S., and SMITH, S.D., "Protecting Distribution Transformers from Low-Side

Current Surges," Proceedings, IEEE T\&D Conference, 1989.

- Discusses effects of the type of windings of the transformer on the resulting surges at the service entrance.

- Recommends installation of SPDs at both transformer secondary and service entrance.

- 7 references

[113] DUGAN, R.B., GOEDDE, G., and HENRY, D.C., "Conduction of Lightning Stroke Currents From the Utility System to Load Devices," Proceedings, $2^{\text {nd }}$ National Conference on Power Quality for End-Use Applications, 1990.

- Describes how lightning surges can enter load circuits through utility system neutral paths.

- Offers comments on protection schemes within the building.

- 4 references

[114] DUGAN, R.B., GOEDDE, G.L., and ROWE, L.D., "Full Scale Lightning Surge Tests of Distribution Transformers and Secondary Systems," Proceedings IEEE PES Transmission and Distribution Conference, Sept., 1991

- Discusses low side surges and effects on distribution transformers.

- Discusses effect of secondary arresters on distribution transformer failures.

- 11 references 
[115] DUGAN, R.C., "Low-Side Surges -Answers to Common Questions," Cooper Power Systems Bulletin SE9001, 1992

- Tutorial presentation of the subject of low-side surges

- Laboratory test results from injection of 4/10 strokes at the transformer primary and at the service entrance.

- 9 references

[116] EHRLER, J. and KÜTTNER, H., "Ausbreitung und Begrenzung von Blitzüberspannungen in Niederspannungs Anlage" [Propagation and Limitation of lightning overvoltages in low-voltage systems], VDE/ABB Blitzschutztagung, 1997. (In German)

[117] EPRI Electromagnetic Transient Program (EMTP), Version 2.0, Vol. 1, Main Program; Vol. 2, Auxiliary Routines, EPRI Report EL-6421-L, July 1989.

- Description of the public domain version of the original EMTP program, adapted for PC use.

[118] ERIKSSON, A.J., STRINGFELLOW, M.F., and MEAL, D.V., "Lightning-induced Overvoltages on Overhead Distribution Lines," IEEE Transactions PAS-101, No.4, 1982.

- Measurement of voltages induced into an 11-kV line, 10-km long, by nearby and far lightning strikes.

- Model for computing induced voltages.

- 24 references, 2 discussions

[119] FERNANDEZ, M.I., MATA, C.T., RAKOV, V.A., UMAN, M.A., RAMBO, K.J., STAPLETON, M.V., and BEJLERI, M. "Testing of Lightning Arresters and Improved Lightning Protection, Final Results," Technical Report, EPRI 109670, 1998.

- Camp Blanding, Florida facility for rocket-triggered lightning.

- Direct lightning strikes to overhead line and to a simulated house ground.

- 25 references

[120] GREBE, J.E., "Application of Distribution System Capacitor Banks and Their Impact on Power Quality," IEEE Transactions IA-32, No.3, May/June 1996.

- Summary of power quality related concerns associated with the application of utility distribution systems capacitor banks.

- 7 references

[121] HENSLEY, G., SINGH, T., SAMOTYJ, M., McGRANAGHAN, M., and GREBE, T.E, "Impact of Utility Switched Capacitors on Customer Systems Part II -- Adjustable Speed Drive Concerns," IEEE Transactions PWRD-6, No.2, October 1991.

- Computer analysis of nuisance tripping of adjustable speed drives caused by capacitor switching

- 8 references

[122] HENSLEY, G., SINGH, T., SAMOTYJ, M., McGRANAGHAN, M., and ZAVADIL,R., "Impact of Utility Switched Capacitors on Customer Systems -- Magnification at Low-Voltage Capacitors," IEEE Transactions PWRD- 7, No.2, April 1992.

- Computer and parametric analysis of secondary transient overvoltages caused by utility capacitor switching.

- 5 references

[123] JOHNSON, I.B., SILVA, R.F., and WILSON, D.D., "Switching Surges Due to Energization or Reclosing," Proceedings, American Power Conference, vol. XXIII, 1961.

- Transient Network Analyzer study.

- 4 references

[124] KEY, T.S. and MARTZLOFF, F.D. “Surging the Upside-Down House: Looking into upsetting reference voltages," Proceedings, EPRI-PQA'94 Conference, Amsterdam, October 1994.

- Describes a test bed for the propagation and mitigation of surges.

- Illustrates the differences of voltage references developed across multiple ports of appliances.

- 8 references

[125] KIMBARK, E.W. and LEGATE, A.C., "Fault Surge Versus Switching Surge - A Study of Transient Overvoltages Caused by Line-to-Ground Faults," IEEE Transactions, PAS-87, No. 9, Sept. 1968.

- Theoretical treatment of the subject.

- 5 references 
[126] LAT, M.V., "Determining Temporary Overvoltage Levels for Application of Metal-Oxide Surge Arresters on Multigrounded Systems," IEEE Transactions PWRD-5, April 1990

- Presents several calculation methods for temporary overvoltages and an evaluation of these methods.

- Defines limits of applicability of the methods.

- 8 references

[127] LIN, Y.T., UMAN, M.A., and STANDLER, R.B., "Lightnıng Return Stroke Models," Journal of Geophysical Research vol.85, No. C3, March 1980.

- Tests the two most commonly used lightning return stroke models. Bruce-Golde and transmission line, against subsequent stroke electric and magnetic field measured simultaneously at near and distant stations and shows that these models are inadequate to describe the experimental data

- A new return stroke model is proposed that is physically plausible and that yields good approximations to the measured two-station fields.

- 38 references

[128] MANSOOR, A. and MARTZLOFF, F.D., "Driving High Surge Currents into Long Cables: More Begets Less," IEEE Transactions PWRD-12, No.3, July 1997.

- Measurements and modeling show the physical impossibility for large surge currents to propagate very far into the branch circuits of a building, because flashover will occur at the service entrance.

- Demonstrates the importance of considering the maximum rate of rise (early in the surge) rather than the peak value and overall rise time.

- 13 references

[129] MANSOOR, A. and MARTZLOFF, F.D., "The Effect of Neutral Earthing Practices on Lightning Current Dispersion in a Low-Voltage Installation," IEEE Transactions PWRD-13, July 1998.

- Compares the TN and TT for dispersion of lightning current in several scenarios.

- Shows the need for careful review of grounding practices in effect at service entrances.

- Questions the applicability of high amplitude, long duration requirement for service entrance SPDs.

- 20 references

[130] MARTZLOFF, F.D., Surge Suppression in a Typical Home Wiring System," Declassified GE TIS Report 63GL97, 1963.

- Injection of voltage surges and their propagation in a residential power system.

- 2 references

[131] MARTZLOFF, F.D. and CROUCH, K. E., "Coordination of Overvoltage Protection in Low-voltage Residential Circuits," - English translation by the author of the original French paper "Coordination de la protection contre les surtensions dans les réseaux basse tension résidentiels," published in Proceedings, 1978 IEEE Canadian Conference on Communications and Power, 78CH1373-0, 1978.

- Reports laboratory injection of lightning current in house wiring.

- Illustrates conversion of unidirectional surges into oscillatory surges

- 4 references

[132] MARTZLOFF, F.D., "Coordination of Surge Protectors in Low-Voltage AC Power Circuits, "IEEE Transactions, PAS-99, No. 1, Jan./Feb. 1980.

- Coordination between gap-type ("voltage switching") and clamp-type ("voltage limiting") protectors

- Coupling between grounding conductor and phase wires

- 7 references

[133] MARTZLOFF, F.D., "The Propagation and Attenuation of Surge Voltages and Surge Currents in Low-Voltage AC Power Circuits," IEEE Transactions PAS-102, No. 5, May 1983

- Propagation and attenuation of $1.2 / 50 \mu \mathrm{s}$ and $100 \mathrm{kHz}$ Ring Wave.

- Coupling of differential mode through isolation transformers.

- 9 references, 1 discussion

[134] MARTZLOFF, F.D. and GAUPER, H.A., "Surge and High-Frequency Propagation in Industrial Power Lines," IEEE Transactions IA-22, No.4, July/August 1986.

- Propagation of $100 \mathrm{kHz}$ Ring Wave in steel conduit lines.

- Options for coupling one, two, or three surge diverters at line end; resulting mode conversion.

- 8 references 
[135] MARTZLOFF, F.D., "Varistor vs environment: Winning the Rematch," IEEE Transactions PWRD-1, April 1986.

- Propagation of low-frequency, capacitor switching ring waves from distant substation to low-voltage load.

- Coordination between $3 \mathrm{kV}$ and $480 \mathrm{~V}$ varistor-based SPDs.

- 5 references, 1 discussion

[136] MARTZLOFF, F.D. and WILSON, P.F., "Fast Transient Tests - Trivial or Terminal Pursuit ?," Proceedings,

$7^{\text {th }}$ International Zürich Symposium on Electromagnetic Compatibility, 1987.

- Measurement and modeling of attenuation of pulses with nanosecond rise time in steel conduit lines.

- 8 references

[137] MARTZLOFF, F.D. and LEEDY, T.F., "Electrical Fast Transients: Application and Limitations," IEEE Transactions IA-26, No. 1, Jan./Feb. 1990.

- Measurement and modeling of attenuation of the EFT 5/50 ns pulse in conduit and non metallic jacket lines.

- Shows the decrease in pulse front steepness occurring for a relatively short leng th of line.

- Suggests that the EFT test should be required only when exposure to this type of environment is likely.

- 9 references

[138] MARTZLOFF, F.D., "Coupling, Propagation, and Side Effects of Surges in an Industrial Building Wiring System," IEEE Transactions IA-26, No. 2, March/April 1990.

- Propagation and attenuation in multi-branch systems.

- Surges in power lines can cause failures of data port components when ground loops exist between pieces of equipment powered by separate branch circuits and connected by a data link.

- Findings promoted the concept of a surge reference equalizer.

- 11 references

[139] MARTZLOFF, F.D., "On the Propagation of Old and New Surges," Proceedings, Open Forum on Surge Protection Application, NISTIR-4654, August 1991.

- Measurements on the propagation of the Ring Wave, the Combination Wave, and the $10 / 1000 \mu$ s Wave.

- The lack of effect of wire diameter is documented by a simple experiment.

- 14 references

[140] MARTZLOFF, F.D., "Diverting Surges to Ground: Expectations vs. Reality," Proceedings, Open Forum on Surge Protection Application, NISTIR-4654, August 1991.

- Comparison of the performance of filter-type vs. voltage-limiting type surge-protective devices.

- Experimental demonstration of voltages induced in branch circuit conductors by the flow of surge currents diverted by the action of the two types of SPDs.

- 9 references

[141] MARTZLOFF, F.D., MANSOOR, A., PHIPPS, K.O., and GRADY, W.W., "Surging the Upside-Down House: Measurement and Modeling Techniques," Proceedings, PQA'95 Conference, New York, NY, 1995.

- Describes a test bed for studying the propagation of surges in low-voltage installations.

- Test and computer modeling on appliances connected to different systems show reference voltage shifts.

- 4 references

[142] MARTZLOFF, F.D., "On the Dispersion of Lightning Current for a Direct Flash to a Building," Proceedings, $25^{\text {th }}$ International Conference on Lightning Protection, Rhodes, 2000.

- A review of simulation examples and anecdotal case history.

- 9 references

[143] MASTER, M.J., UMAN, M.A., LIN, Y.T., and STANDLER, R.B., "Calculations of Lightning Return Stroke Electric and Magnetic Fields above Ground," Journal of Geophysical Research vol.86, No.C12, Dec. 1981.

- Detailed calculations of lightning return stroke electric and magnetic fields above ground are presented.

- 16 references

[144] MATA, C.T., FERNANDEZ, M.I., RAKOV, V.A., UMAN, M.A., BEJLERI, M., RAMBO, K.J., and STAPLETON, M.V., "Overvoltages in Underground Systems, Phase 2 Results," Technical Report, EPRI TR-109669-R1, 1998.

- A 200-page report on the results of triggered lightning experiments.

- 43 references 
[145] MATA, C.T., FERNANDEZ, M.I., RAKOV, V.A., and UMAN, M.A., "EMTP Modeling of a Triggered-Lightning Strike to the Phase Conductor of an Overhead Distribution Line," IEEE Transactions PWRD - ( Scheduled for Spring 2002).

- Modeling of the Camp Blanding overhead distribution line subjected to injection of lightning current.

- Model elements include transmission line, MOV arresters, grounding leads, and ground rods.

- 9 references

[146] MIKHAIL, S. and McGRANAGHAN, M, "Evaluation of Switching Concerns Associated with 345 kV Shunt Capacitor Applications," IEEE Transactions PAS-106, No.4, April 1986

- Results of Transient Network Analyzer study evaluating switched capacitor banks.

- Includes normal energizing, voltage magnification, phase-to-phase transients, inrush, outrush, and restrikes

- 14 references, 2 discussions

[147] NIGGLI, M.R., YTURRALDE, W.E., NIEBUHR, W.D., ROCAMORA, R.G., and MADZAREVIC, V., "Fault Clearing Overvoltages on Long Transformer Terminated Lines," IEEE Transactions, PAS-98, No. 2, March 1979

- Transient Network Analyzer study

- 9 references, 4 discussions

[148] PAUL, C.R. and HARDIN, K.B., "Diagnosis and Reduction of Conducted Noise Emissions," IEEE Transactions, EMC, Nov. 1988.

- Method for determination of relative value of common-mode and normal-mode noise, with modeling of candidate mitigation methods.

- 5 references

[149] PFEIFFER, W. and GRÄF, T., "Ausbreitung und Dämpfung von Überspannungen in NiederspannungsInstallationen" [Propagation and Damping of Overvoltages in Low-voltage Installations], Elektrie Bd. 48,1994 - A review of the propagation of surge voltages (in German).

[150] RAKOTOMALALA, A., ROUSSEAU, A., and AURIOL, P., "Lightning Distribution Through Earthing Systems," Proceedings, IEEE International Symposium on EMC, 1994.

- Model of electrical installation including power and telecom lines, water pipe, lightning rod and SPDS

- Sharing of current between various paths including SPDs showing that neutral is more stressed in case of strike on lightning rod. Opposite in case of strike on power lines.

- In general $30 \%$ of lightning current is shared among all power conductors.

- 8 references

[151] RAKOV, V.A., UMAN, M.A., FERNANDEZ, M.I., MATA, C.T., RAMBO, K.J., STAPLETON, M.V., and SUTIL, R.R., "Direct Lightning Strikes to the Lightning Protection System of a Residential Building: Triggered-lightning Experiments," IEEE Transactions PE-032PRD(11-2001)

- Injection of triggered lightning into a house replica at Camp Blanding.

- Measured data on dispersion of the lightning current among available paths to ground

- Examples of current waveforms.

- 9 references

[152] ROCHEREAU, H., XEMARD, A., MICHAUD, J., ZEDDAM, A., and BOUTET, F., "ANASTASIA: Un outil de simulation de l'effet de la foudre sur les réseaux aériens de distribution à basse tension" [ANASTASIA: A Simulation Tool for Lightning Effects on Overhead Low-voltage Distribution Lines], Proceedings, CIGRE Conference "Power system electromagnetic compatibility" - Foz do Iguaçu - May 1995

- Reports an investigation conducted by the French utility (in French).

[153] ROUSSEAU, A., ROY, D., and WARSMANN, P., "What is a Lightning Earth ?" ERA Earthing 2000

- Mathematical model of high frequency lightning earth/ground.

- High frequency is just useful for overvoltages not for energy sharing between various paths.

- Equipment exist for measuring high frequency ground impedance and examples of good "lightning" ground are given based on real measurements.

- 5 references

[154] SCUKA, V., "EMI Control in Low-Voltage Power Installations." Proceedings, 7"' International Zürich Symposium on Electromagnetic Compatibility, 1987.

- Laboratory measurements of propagation parameters on typical wiring practices

- Comparisons between gap-type and varistor SPDs.

- Recommendations on grounding practices and building construction.

- 8 references 
[155] STANDLER, R.B., "Equations for Some Transient Overvoltage Test Waveforms," IEEE Transactions EMC30, Feb. 1988.

- Provides mathematical equations for the $100 \mathrm{kHz}$ Ring Wave and the Combination Wave.

[156] STANDLER, R.B., "Calculation of Lightning Surge Currents Inside Buildings," Proceedings, IEEE EMC Symposium, August 1992.

- Makes computations with SPICE for a 10/350 $\mu$ s, 20 kA impinging current.

- MOV arrester at the service entrance and varistors at the end of branch circuits of various lengths.

- Neglects inductance and considers only resistance, justified by the long tail of the surge.

- 11 references

[157] STANDLER, R.B., "Transmission Line Models for Coordination of Surge-protective Devices," Proceedings, IEEE International Symposium on Electromagnetic Compatibility Symposium, 1993.

- The distribution of surge currents between an arrester and suppressor separated by a transmission line is described for six different models of transmission lines.

- Two different surge waveforms are used in the simulation: the 1.2/50 $\mu$ s wave, and the $10 / 350 \mu$ s wave.

- Conclusions on the relative accuracy of the various models of transmission lines.

- 14 references

[158] STANDLER, R.B., "Neutral-Earth Surge Voltages on Low-voltage AC Mains," Proceedings, $10^{\text {th }}$ International Zürich Symposium on Electromagnetic Compatibility, 1993

- Computer simulations of surge suppressor circuits and propagation of surges on transmission lines show surge voltage waveshapes between the neutral and protective earth conductors inside buildings.

- Theoretical discussion is about the common error of approximating a transmission line as a single inductor.

- 13 references

[159] STRINGFELLOW, M.F. and STONELY, B.T., "Coordination of Surge Suppressors in Low-Voltage AC Power Circuits," Proceedings, Forum on Surge Protection Application, NISTIR-4657, August 1991.

- Experiments showing the effect of line length and surge waveform on sharing energy between service entrance arrester and surge suppressor inside building.

- Metal-oxide varistors were applied at service entrance, distribution panel and load.

- Removal of protection at either load or distribution panel resulted in unacceptably large oscillatory voltages. Best load protection achieved with MOVs in all three locations.

- 4 references

[160] VINES, R.M., TRUSSELL, H.G., GALE, L.J., and OAENEAL, B., "Noise on Residential Power Distribution Circuits," IEEE Transactions, EMC, Nov. 1984.

- Reports conducted noise measurements from typical residential loads.

- 14 references

[161] WIITANEN, D.O., MORGAN, J.D., and GAIBROIS, G.L., "Station Capacitor Switching Transients Analytical and Experimental Results," IEEE Transactions, PAS-90, No. 4, April 1971.

- Switching transients at the $41 \mathrm{kV}$ level.

- 10 references, 2 discussions

$-0-0-0-0-0-0-0-0-0-$ 


\section{Monitoring instruments, laboratory measurements and test methods}

[162] ALLEN, G.W., "Design of Power-Line Monitoring Equipment," IEEE Transactions, PAS-90, May 1971

- Description of the instrumentation used by Allen and Segall in [53]

- 5 references

[163] BULL, J.H., "Impedance of the Supply Mains at Radio Frequencies," Proceedings, $2^{\text {"t }}$ Symposium on Electromagnetic Compatibility, Montreux, 1975.

- Reports measurements and $50 \Omega / 50 \mu \mathrm{H}$ equivalent circuit.

- 6 references

[164] BUSCHKE, H.A., "A Practical Approach to Testing Electronic Equipment for Susceptibility to AC Line Transients," IEEE Transactions on Reliability, vol. 37, No. 4, Oct. 1988.

- Describes test methods and test circuits developed independently from standard approaches.

- 3 references

[165] CUMMINS, K.L., KRIDER, E.P., and MALONE, M.D., "The U.S. National Lightning Detection Network TM and Applications of Cloud-to-Ground Lightning Data by Electric Power Utilities," IEEE Transactions EM-40 No.4, November 1998

- Discusses the principle of lightning detection.

- Provides guidelines on the uncertainties of lightning parameters that are acceptable in the industry.

- 75 references

[166] FISHER, F.A. and MARTZLOFF, F.D., "Transient Control Level Philosophy and Implementation, Part II: Techniques and Equipment for Making TCL Tests," Proceedings, $2^{\text {rd }}$ Symposium on Electromagnetic Compatibility, Montreux. 1977.

- Second part of a paper proposing a test protocol based on concepts derived from high-voltage BIL testing.

- General discussion of circuits for surge generators.

[167] HASSE, P. and BIRKL, J., "EMV-Testverfahren zur Ableiterkoordination" [EMC Test Procedures for Coordination of Surge Protective Devices], EMC Kompendium 1998, pp 112-115.

- Proposes to define a "steepness factor" to characterize the initial rate of rise of current.

[168] KEY, T.S. and MARTZLOFF, F.D. "Surging the Upside-Down House: Looking into Upsetting Reference Voltages," Proceedings, EPRI-PQA 94 Conference, Amsterdam, October 1994

- Describes a test bed for the propagation and mitigation of surges.

- Illustrates the differences of voltage references developed across multiple ports of appliances.

- 8 references

[169] KEY, T.S., MANSOOR, A and MARTZLOFF, F.D., "No Joules for Surges: Relevant and Realistic Assessment of Surge Stress Threats," Proceedings, IEEE International Conference on Harmonics and Power Quality, Las Vegas NV, Oct. 1996.

- Challenges the erroneous concept of characterizing "energy in the surge" from a simple voltage measurement.

- Lists surge parameters leading to failure of specific equipment.

- 15 references

[170] KREISS, D.G., The Dranetz Field Handbook for Power Quality Analysis, Dranetz Technologies, Inc., Edison NJ.

- One chapter on planning and performing a power quality survey includes the topic of 'impulses'.

- One chapter on waveforms shows examples of recorded surges.

[171] LINDES, G., MANSOOR, A., MARTZLOFF, F.D., and VANNOY, D., "Surge Recordings That Make Sense: Joules Deposition: Yes! - 'Joule Content': Never!," Proceedings, PQA'97 USA, 1997

- Challenges the erroneous concept of "energy in the surge" based on a simple voltage measurement.

- Lists surge parameters leading to failure of specific equipment.

- Proposes the approach for using existing power quality monitors to record available surge currents.

- 24 references 
[172] MANSOOR, A., MARTZLOFF, F.D., and PHIPPS, K. "The Fallacy of Monitoring Surge Voltages: SPDs and PCs Galore!," Proceedings, EPRI PQA'99 Conference, May 1999.

- Experimental measurements of effective mitigation by multiple SPDs.

- Numerical simulation of the effect of proliferating SPDs and PCs.

- Calls for an industry-wide reassessment of surge monitoring parameters.

- 18 references

[173] MARKEL, L.C., MELHORN, C.J., WILLIAMS, S.R., and MEHTA, H., "Design of a Measurement Program to Characterize Distribution System Power Quality," CIRED $12^{\text {th }}$ International Conference on Electricity Distribution, 1993.

- Simplification of a system-wide survey through stratified random sampling.

[174] MARTZLOFF, F.D., "Surge Suppression in a Typical Home Wiring System," Declassified GE TIS Report 63GL97, 1963.

- Injection of surges and their mitigation in a residential power system.

- Examples of suppression achieved by selenium cells before the advent of metal-oxide varistors.

- 2 references

[175] MARTZLOFF, F.D., "Surge Withstand Capability of Various Devices," Declassified GE TIS Report 63GL133, 1963.

- Early internal GE report addressing the emerging problem of semiconductor failures caused by surges.

- Speculation on the cause of bulb failure - See [25] Bachl et al. (1997) for progress in understanding.

[176] MARTZLOFF, F.D., "Effect of Rate of Voltage Rise on Reverse Breakdown of Silicon Diodes." Declassified GE TIS Report 63GL132, 1963.

- Steep front surges tend to increase the level at which 1960's diodes failed under surge conditions.

- Higher peak inverse voltage (PIV) do not result in higher levels for the surges that cause failure.

[177] MARTZLOFF, F.D., "Low Cost Surge Counter," Declassified GE TIS Report 64GL166, 1964.

- Design of the surge counters used for the surge monitoring reported in [86] Martzloff \& Hahn, 1970.

[178] MARTZLOFF, F.D., "Semiconductor Performance under Reverse Transient Over-voltages," Declassified GE TIS Report 67C-066, 1966.

- For semiconductors of the late sixties vintage, there is no correlation between their peak inverse voltage rating (PIV) and the surge level at which failure occurs - most likely by edge flashover.

- Ageing by storage at elevated temperature changed the PIV but not the surge failure level.

- 8 references

[179] MARTZLOFF, F.D., "Transient Control Level Test Generators." Unclassified GE TIS Report 77CRD241, 1977.

- Development of a home-made Ring Wave generator used in the seventies and eighties.

- Two examples of circuits with identical open-circuit voltage waveforms, but different short-circuit current waveforms.

- 8 references

[180] MARTZLOFF, F.D., Discussion of IEEE paper by Aspnes, J.D., Evans, B.W., and Merritt, R.P., "Rural Alaska Power Quality," IEEE Transactions PAS-104, No. 4, March 1985.

- Signals the fallacy of surge recordings from a monitoring instrument that included an internal SPD to protect its own power supply, inadvertently mitigating surges on the receptacle also used as power source to be monitored.

[181] MARTZLOFF, F.D., "Surge Testing: Don't Kid Yourself, Don't Kill Yourself !" EMC Technology and Interference Control News, August 1988.

- Overview of the just-then-published IEEE Guide on Surge Testing, C62.45-1987.

[182] MARTZLOFF, F.D. and PELLEGRINI, G., "Real, Realistic Ring Waves for Surge Testing," Proceedings, $9^{\text {th }}$ International Zürich Symposium on Electromagnetic Compatibility, 1991.

- Reports measurements on the propagation of oscillatory waves in typical low-voltage circuits, as opposed to the unidirectional waves initially defines for high-voltage power systems.

- Shows how impinging unidirectional surges can produce oscillatory waves responses.

- 17 references 
[183] MARTZLOFF, F.D., "Keeping up with the Reality of Today's Surge Environment," Proceedings, Power Quality '95 Conference, 1995.

- Explains that monitoring voltage surges no longer makes sense because of the proliferation of SPDs

- Rebuts the misconception of characterizing surges by their "energy content."

- Proposes an IEEE-sponsored sharing of field failure data as an assessment of the surge environment.

- 15 references

[184] MARTZLOFF, F.D., "Surge Recordings That Make Sense: Shifting Focus from Voltage to Current Measurements," Proceedings, EMC ROMA 96 Symposium, 1996.

- Makes the case that the proliferation of SPDs makes monitoring surge voltages debatable.

- Proposes an approach for using existing power quality monitors to record available surge currents

- 18 references

[185] MARTZLOFF, F.D. and FISHER, F.A., "Transient Control Level Philosophy and Implementation, Part 1: The Reasoning Behind the Philosophy," Proceedings, 2nd Symposium on Electromagnetic Compatibility, Montreux, 1977.

- Techniques and equipment for making TCL tests

- 10 references

[186] McEACHERN, A., Handbook of Power Signatures, Basic Measuring Instruments, Foster City CA, 1989.

- Reports generic types of disturbances with non-standard terminology.

- Calls a surge as defined by IEEE an 'im pulse'. Calls a swell as defined by IEEE a 'surge'

- Describes procedures on conducting a site survey.

- 267 pages

[187] MILLANTA, L.M. and FORTI, M.M., "A Notch-Filter Network for Wide-Band Measurements of Transient Voltages on the Power Line," IEEE Transactions on EMC. Aug. 1988.

- Describes the design and characteristics of a probe that filters out the power-frequency component.

- 20 references

[188] MILLANTA, L.M., FORTI, M.M., and MACI, S.S., "A Broad-Band Network for Power-Line Disturbance Voltage Measurements," IEEE Transactions EMC-30, No.3, Aug. 1988.

- Filter network removing the power-frequency voltage from the record.

- 5 references

[189] MILLANTA, L.M. and FORTI, M.M., "A Classification of the Power-Line Voltage Disturbances for an Exhaustive Description and Measurement," Proceedings, IEEE EMC Symposium, 1989.

- Proposal for systematic classification of disturbances.

- 17 references

[190] NAVE, M.J., "A Novel Differential Mode Rejection Network for Conducted Emissions Diagnostics," Proceedings, IEEE EMC Symposium, 1989.

- Discussion of common mode and differential mode from the point of view of frequency domain measurements.

- 5 references

[191] RICHMAN, P., "Precision Coil Impulse Testing with 0.3 A, Micro-Breakdown Sensitivity," Power Conversion International, vol. 8, No. 5, May 1982.

- General review of surge generator technology.

- Detection of breakdown by monitoring both voltage and current waveforms in EUT.

- 11 references

[192] RICHMAN, P., "Single-Output, Voltage and Current Generation for Testing Electronic Systems," Proceedings, IEEE 1983 EMC Symposium, 1983

- Presents the case for the Combination Wave rather than separate $1.2 / 50 \mu \mathrm{s}$ and $8 / 20 \mu$ s impulses.

- 4 references

[193] RICHMAN, P., "Changes to Classic Surge-Test Waves Required by Back-Filters Used for Testing Powered

Equipment," Proceedings, $6^{h}$ Symposium on Electromagnetic Compatibility Zürich, 1985.

- Undershoot effects on unidirectional waves, the case for oscillatory waves.

- 5 references 
[194] SENKO, G., "Probes and Techniques for Measuring Surge Voltage Waves with Fronts from 10 ns to $1.2 \mu s$ and Peaks to $10 \mathrm{kV}$," Proceedings, $7^{\text {th }}$ International Zürich Symposium on Electromagnetic Compatibility, 1987.

- Describes a differential probe with $10 \mathrm{k} \Omega$ input impedance, $2 \mathrm{~ns}$ rise time, $10 \mathrm{kV}$ rating.

- 5 references

[195] SHAKARJIAN, D.R and STANDLER, R.B., "AC Power Disturbance Detector Circuit," IEEE Transactions PWRD-6, No.2, April 1991.

- Design, construction, and performance of a circuit that detects transients on low-voltage AC mains.

- The disturbance detector circuit can be used to trigger a digital waveform recorder or to operate a counter circuit to simply record the occurrence of a disturbance.

- 7 references

[196] STANDLER, R.B., "An Experiment to Monitor Disturbances on the Mains," Proceedings, IEEE IAS Annual Meeting. Oct. 1987.

- Experiment to collect waveforms of mains disturbances and determine energy deposited in MOVs.

- 16 references

[197] STANDLER, R.B., "An Experiment to Monitor Disturbances on the Mains," Conference Record of the 1987 IEEE Industry Applications Society Annual Meeting, 1987.

- Describes the design of an experiment to characterize disturbances on the mains, including the trigger criteria for waveform recorders

- Definitions of some disturbances are provided.

- 16 references

[198] STANDLER, R.B., "Equations for Some Transient Overvoltage Test Waveforms," IEEE Transactions EMC30, No.1, February 1988.

- Simple equations are provided that satisfy the definitions of five of the most common transient overvoltage test waveforms: the Ring Wave specified in ANSI C62.41-1980, the fast transient specified in IEC 801, and the $8 / 20-\mu s$ s.2/50- $\mu$ s, and $10 / 1000-\mu s$ waveforms.

- 7 references

[199] STANDLER, R.B., "Standard Waveforms for Surge Testing: Experimental Evaluation and Proposed New Criteria for Tolerances," Proceedings, $8^{\text {h }}$ International Zürich Symposium on Electromagnetic Compatibility, 1989.

- Evaluates several commercial surge generators and proposes using equations to define nominal waveforms and tolerances of unipolar waves.

- 11 references

[200] STANDLER, R.B., "Calculation of Energy in Transient Overvoltages," Proceedings, IEEE EMC Symposium, 1989.

- Shows that using the integral of $V^{2} / 50 \Omega$. dt to compute energy in a surge is invalid.

- An artificial AC line network simulates a long branch circuit to give line impedance vs. frequency.

- 18 references

[201] STANDLER, R.B., "American Surge Test Methods for Equipment Connected to the Low-voltage AC Supply Mains," Proceedings, Lightning Protection 92 - Buildings, Structures and Electronic Equipment Conference 1992.

- Describes how electronic equipment and surge protective devices are surge tested in the USA, with emphasis on differences between the American and European practices.

- 11 references

[202] UMAN, M.A., RAKOV, V.A., RAMBO, K.J., VAUGHT, T.W., FERNANDEZ, M.I., BERNSTEIN, R., and GOLDEN, C., "Triggered-lightning Facility for Studying Lightning Effects on Power Systems," Proceedings, $23^{\text {th }}$ International Conference on Lightning Protection, Florence, Italy, 1996.

- Description of rocket-triggered lightning at Camp Blanding, with examples of recordings.

- 6 references

[203] WIESINGER, J., "Hybrid-Generator für die Isolationskoordination," (Hybrid Generators for the Coordination of Insulation) ETZ-104, No. 21, 1983.

- Endorses the concept of the Combination Wave in the European context. 


\section{Textbooks and tutorial reviews}

[204] BODLE, D.W., GHAZI, A.J., SYED, M., and WOODSIDE, R.L. Characterization of the Electrical Environment. Toronto and Buffalo, NY. University of Toronto Press, 1976.

- Book initially written from the communications point of view but applicable to AC power circuits.

- 124 references, 320 pages

[205] CIGRE Working Group 33.10, "Temporary Overvoltages: Causes, Effects and Evaluation," Paper 33-210. CIGRE Conference 1990, Paris.

- Overview on causes of temporary overvoltages on HV networks and impact on surge arresters.

- Equipment withstand capability and methods of temporary overvoltages control.

- 23 references

[206] DAVIES, D.W. and STANDLER, R.B., "Ball Lightning," Nature vol.240, No.5377, November 1972.

- A well published photograph purportedly of ball lightning has been critically examined.

- Evidence is stronger for interpreting the photograph as a street lamp rather than lightning ball.

- 7 references

[207] DE LA ROSA, F., NUCCI, C.A., and RAKOV. V.A., "Lightning and Its Impact on Power Systems," CIGRE Paper P.34, International Conference on Insulation Coordination for Electricity Development in Central

European Countries, Zagreb, Croatia, 1998.

- Comprehensive (44 pages) review of the subject.

- 102 references

[208] DUGAN, R.C., "Low-Side Surges - Answers to Common Questions," Cooper Power Systems Bulletin SE9001, 1992

- Tutorial presentation of the subject of low-side surges

- Laboratory test results from injection of 4/10 strokes at the transformer primary and at the service entrance.

- 9 references

[209] FERNANDEZ, M.I., RAMBO, K.J., RAKOV, V.A., and UMAN, M.A., "Performance of MOV Arresters During Very Close, Direct Lightning Strikes to a Power Distribution System," IEEE Transactions PWRD-14, No.2, 1999.

- Injection of triggered lightning current into an overhead distribution line with MOV arresters at Camp Blanding.

- Measurements of the response of the arresters to the lightning current.

- 8 references, one discussion

[210] FISHER, F.A. and MARTZLOFF, F.D., "Transient Control Levels: A Proposal for Insulation Coordination in Low-Voltage Systems," IEEE Transactions PAS-95, No. 1, Jan/Feb 1976.

- Proposes parallel with the BIL concept for high-voltage system

- First published version of a test circuit for $100 \mathrm{kHz}$ Ring Wave

- 12 references, 3 discussions

[211] FISHER, F.A. and MARTZLOFF, F.D., "Transient Control Level Philosophy and Implementation, Part II:

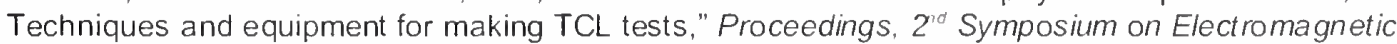
Compatibility, Montreux, 1977.

- Second part of a paper proposing a test protocol based on concepts derived from high-voltage BIL testing

- General discussion of circuits for surge generators.

[212] GOLDE, R.H., Ed. Lightning, New York: Academic Press, 1977.

- Vol 1: Physics of lightning

- Vol 2: Lightning protection

- Several hundred references

[213] GREENWOOD, A., Electrical Transients in Power Systems Wiley-Interscience, New York, 1971.

- Comprehensive textbook.

- Cites 2.1 per-unit overvoltage during ground fault clearing.

- 210 references, 540 pages 
[214] GRUZS, T.M., "Power Disturbances and Computer Systems: A Comparison of the Allen-Segall and the Goldstein-Speranza Power Line Monitoring Studies," Proceedings, 1986 Electrical Overstress Exposition, Nelson Pub. 1986.

- The effect of arbitrary threshold selection on statistics.

-2 references

[215] HASSE, P., Overvoltage Protection of Low-Voltage Systems. IEE Power Series, Peter Peregrinus Ltd. London, 1992. (Original German edition in 1987) Available in the U.S. from IEEE - Second Edition, 2000.

- Examples of causes of overvoltages and damage to electrical systems with electronic devices.

- The operation and application of proven overvoltage protection devices are considered.

- Discusses coordination with a "quenching gap" as the upstream SPD.

- 355 pages, 83 references (many in German)

[216] IEEE Committee Report. "Bibliography on Surge Voltages in AC Power Circuits Rated 600 Volts or Less," IEEE Transactions, PAS-89, No. 6, July/Aug. 1970.

- Bibliography compiled by the original IEEE working group 3.6.4

- 73 references

[217] KEY, T.S., “Diagnosing Power Quality-Related Computer Problems," IEEE Transactions IA-15, No. 4, July 1979.

- Records of disturbances and general discussion.

- The seminal proposal of the computer susceptibility curve now known as "The CBEMA Curve".

- 10 references

[218] KEY, T.S. and MARTZLOFF, F.D., "A Consensus on Powering and Grounding Sensitive Electronic Equipment," Conference Record, IEEE-IAS Annual Meeting, October 1986.

- General tutorial discussion of the subject.

- Proposed computer susceptibility curve.

- 19 references

[219] KEY, T.S., NASTASI, D., PHIPPS, K.O., MARTZLOFF, F.D., MAY, J., "Update on a Consumer-Oriented Guide for Surge Protection," Proceedings, PQA'90 Conference, Charlotte NC, May 1999.

- Summary of a comprehensive report developed by a team of experts, sponsored by EPRI.

- Presents three reports of case studies on lightning damage and post-mortem tests.

- 9 references

[220] MARTZLOFF, F.D. and FISHER, F.A., "Transient Control Level Philosophy and Implementation, Part I: The reasoning behind the philosophy," Proceedings, $2^{\text {nd }}$ Symposium on Electromagnetic Compatibility,

Montreux, 1977.

- First part of a paper proposing a test protocol based on concepts derived from high-voltage BIL testing

- Equipment should be designed and rated to withstand a limited set of surge tests rather than attempting to emulate "real world" but ill-defined surge events.

- 10 references

[221] MARTZLOFF, F.D., Discussion of IEEE paper by Aspnes, J.D., Evans, B.W., and Merritt, R.P., "Rural Alaska power quality," IEEE Transactions PAS-104, No. 4, March 1985

- Signals the fallacy of surge recordings from a monitoring instrument that included an internal SPD to protect its power supply, inadvertently mitigating surges on the dual receptacle used for monitoring.

[222] MARTZLOFF, F.D., "Tigers or Pussycats: Does Distance Make the Difference ?" BICSI Newsletter, October 1988.

- Discussion of the background leading to testing for the propagation if the IEC "Electrical Fast Transient".

[223] MARTZLOFF, F.D., "Tiger Tempering Tampers Transmissions," B/CSI Newsletter, December 1988.

- A summary of tests on the propagation of surges in a building and the side effects of installing SPDs.

[224] MARTZLOFF, F.D. and GRUZS, T.M., "Power Quality Site Surveys: Facts, Fiction, and Fallacies," IEEE Transactions IA-24, No. 6, Nov/Dec 1988.

- Review of instrumentation development, definition deficiencies, and past survey results.

- First proposal of the term "swell".

- 33 references

[225] MARTZLOFF, F.D., "Power Quality Measurements: Bringing Order Out of Chaos," Proceedings, 1988 Energy Technology Conference, Feb. 1988.

- Condensation of Martzloff/Gruzs paper for power-quality context.

- 16 references 
[226] MARTZLOFF, F.D. and GRUZS, T.M., "Monitoring Power Quality," Powertechnics Magazine, February 1990. "Systems and Instruments in Site Surveys," Powertechnics Magazine, March 1990.

- Trade magazine version, in two successive articles, of the 1988 Martzloff/Gruzs IEEE paper

- 14 references

[227] MARTZLOFF, F.D. and LEEDY, T.F., "A Glimpse at Long-term Effects of Momentary Overvoltages on Zincoxide Varistors," Transactions Ceramics Society, Vol 3, October 1989

- Overview on the issue of ageing metal-oxide varistors subjected to repetitive momentary overvoltages ("swells").

- Computations of temperature rise in the varistor body during a swell.

- Preliminary experiments on ageing (see later experiments under [259] Lagergren et al., 1992).

- 5 references

[228] MARTZLOFF, F.D., "Protecting Computer Systems Against Power Transients," IEEE Spectrum, April 1990

- Brief review of the origin of transients.

- Explanation of and remedy for interaction between power port and communications port.

[229] MARTZLOFF, F.D., "A Standard for the 90s: IEEE C62.41 Surges Ahead," Compliance Engineering, Fall 1991.

- Trade magazine review of the revised and expanded C62.41 in its 1991 issue.

- 5 references

[230] MARTZLOFF, F.D., "What Are the Lights on Your Surge Protector Telling You," Power Quality Assurance, Intertech Intl., Inc. (Jul/Aug 1998).

- Cites the ambiguity in the status indications of surge-protective devices.

- Describes two failure modes and conflicting indications.

[231] MARTZLOFF, F.D., "Surges Happen! - How to protect the appliances in your home," Special Publication 960-6, National Institute of Standards and Technology, May 2001.

- Consumer-oriented tutorial on the origins of surges and ways to mitigate them.

- Questions and answers, installation hints.

- 20 pages

[232] PODGORSKI, A.S., "A Case for a Unified Lightning Threat," Proceedings, International Aerospace and Ground Conference on Lightning and Static Electricity, Oklahoma City, 1988.

- Measurements of lightning currents on tall towers and aircraft.

- Reports current rise times in the 50 ns to 100 ns range.

- 14 references

[233] RAKOV, V.A., "Lightning Electromagnetic Fields: Modeling and Measurements," Proceedings, $12^{\text {th }}$ International Zürich Symposium on Electromagnetic Compatibility, 1997.

- Review of various models proposed to simulate lightning stroke events

- Comparison of model predictions and measurements of electromagnetic fields.

- 34 references

[234] RAKOV., V.A., "Lightning Electric and Magnetic Fields," Proceedings, $13^{\text {th }}$ International Zürich Symposium on Electromagnetic Compatibility, 1999.

- Review of measured characteristics of the electric and magnetic fields.

- Examples of different types of field waveforms are given.

- 12 references

[235] RHOADES, W.T., "Designing Commercial Equipment for Conducted Susceptibility," Proceedings. IEEE EMC Symposium, 1979.

- Discusses unprotected product input impedances, transient propagation modes and models, measured transient occurrences, and typical susceptibility.

- 9 references

[236] RHOADES, W.T., "Development of Power Main Transient Protection for Commercial Equipment,"

Proceedings, IEEE EMC Symposium, 1980

- Class distinction of the various wide-range transients from arc to motor turn-on.

- Low product immunity to common-mode transients is shown to be caused by high energy-density spectrum.

- 18 references 
[237] RHOADES, W.T., "The Ratiocination of a Commercial Power Main Conducted Susceptibility Standard," Proceedings, IEEE EMC Symposium, 1981.

- Review of transient types, standards, definitions, and cost considerations.

- 18 references

[238] RHOADES, W.T., "Critical Analysis of Commercial Power Main Transient Designs," Proceedings, IEEE EMC Symposium, 1987.

- Review of environment, statistics, measurements, and standards.

- 38 references

[239] RHOADES, W.T., "Congruence of Low Voltage Main Transient Designs," Proceedings, IEEE EMC Symposium, 1989.

- Survey of the literature on surge occurrence, equipment design, and surge standards.

- 4 references

[240] ROUSSEAU, A. and GUMLEY, R. "Surge Protection" Wiley Encyciopedia of Electrical and Electronics Engineering, 1999.

- Complete review of SPD specifications and characteristics for both telecom and power SPDs including important parameters for selection and comparison.

- Installation rules for SPDs including special case of TNC-S systems .

- 23 references

[241] STANDLER, R.B., Protection of Electronic Circuits from Overvoltages, Wiley-Interscience, New York, 1989.

- Comprehensive review of the origin and propagation of surges, surge-protective devices and applications in circuits, and high-voltage laboratory testing techniques.

- 260 references, 434 pages

[242] UMAN, M.A., RAKOV, V.A., RAMBO, K.J., VAUGHT, T.W., FERNANDEZ, M.I., BERNSTEIN, R., and GOLDEN, C., "Triggered-lightning Facility for Studying Lightning Effects on Power Systems," Proceedings, $23^{\text {th }}$ International Conference on Lightning Protection, Florence, Italy, 1996.

- Description of rocket-triggered lightning at Camp Blanding.

- Examples of recordings.

- 6 references

[243] WIESINGER, J. and HASSE, P., Handbuch für Blitzschutz und Erdung [Handbook for Lightning Protection and Grounding]. Pflaum-Verlag, München; VDE-Verlag, Berlin; 1. Auflage, 1977.

- Handbook addressing types of lightning and their parameters, electric and magnetic fields.

- Protected volume by intercepting devices, overvoltage protection, earthing systems.

- 154 pages, 83 references (German and English) 


\section{Mitigation techniques}

[244] BENDA, S., Interference-Free Electronics. Chartwell Bratt Ltd. Bromley BR1 2NE, U.K

- The design and use of interference-free systems and printed circuit boards

- The emphasis of the book is on equipment design.

[245] BIRD, A.O., "The Effects of Installation Practice on the Performance of Transient Voltage Surge Suppressors," Proceedings, Open Forum on Surge Protection Application. NISTIR 4657, 1991.

- Review of issues such as length of connecting leads and provision of SPD disconnectors (fuses).

- Cascade coordination.

- 11 references

[246] BIRRELL, D. and STANDLER, R.B., "Failure of Surge Arresters on Low-Voltage Mains," IEEE Transactions PWRD-8, No.1, April 1991.

- Use of a secondary arrester on LV AC supply mains to prevent damage to electronic equipment is addressed.

- Some failure mechanisms of secondary arrester are described, and ways to minimize risks from possible failure of the arrester are suggested.

- 36 references

[247] CORBETT, M.P. and WOLFF, B.I., "Performance of MOV Suppressors in Low-Voltage AC power Circuits," Proceedings, Open Forum on Surge Protection Application, NISTIR 4657, 1991.

- Gives examples of connection cónfigurations of MOVs and their coordination

- 8 references

[248] DARVENIZA, M., "Multipulse Lightning Currents and Metal-Oxide Arresters," IEEE Transactions PWRD-12. July 1997.

- Reports differences noted between tests with single standard pulses and multiple closely-spaced pulses.

- Suggests that mechanisms other than mere total energy deposition might be involved.

- Proposes such a multiple test sequence in assessing SPD performance.

- 9 references

[249] DAVIDSON, R., "Suppression Voltage Ratings on UL Listed Transient Voltage Suppressors," Proceedings, Forum on Surge Protection Application, NISTIR-4657, August 1991

- Some advertizing statements claim that the minimum 330 volt suppression rating in UL Standard for Transient Voltage Surge Suppressors, UL 1449, is "the best UL rating" or that 330 volts affords "the most protection possible" or that "the lower the suppression rating the better the TVSS product.

- The ability of a TVSS to protect connected equipment from both upset and damage may depend on a number of factors including knowledge of both the susceptibility and vulnerability of the particular equipment. When these factors are not known, claims that one TVSS provides better protection than another, solely on the basis of the UL 1449 suppression voltage rating, may be misleading.

[250] DUGAN, R.C., KERSHAW, S.S., and SMITH, S.D., "Protecting Distribution Transformers from Low-side Current Surges," Proceedings, IEEE T\&D Conference, 1989.

- Discusses effects of the type of windings of the transformer on the resulting surges at the service entrance.

- Recommends installation of SPDs at both transformer secondary and service entrance.

- 7 references

[251] DUGAN, R.B., GOEDDE, G. and HENRY, C., "Conduction of Lightning Stroke Currents From the Utility System to Load Devices," Proceedings, $2^{\text {nd }}$ National Conference on Power Quality for End-Use Applications, 1990.

- Describes how lightning surges can enter load circuits through utility system neutral paths.

- Offers comments on protection schemes within the building.

- 4 references

[252] GOEDDE, G.L., KNABE, E.S., and KOJOVIC, L.A., "Overvoltage Protection of Distribution and Low-Voltage Equipment Experiencing Sustained Overvoltages," IEEE Winter Meeting, 1999.

- Describes the overvoltages involved in commingling incidents of MV lines dropping on LV lines.

- Reports laboratory tests on distribution arresters.

- 4 references 
[253] GREBE, T.E. and DEAM, D.R., "Evaluation of Distribution Capacitor Switching Concerns, Final Report," EPRI TR-107332, October 1997.

- Provides the results of a joint EPRI/NRECA effort to evaluate the state-of-the-art in distribution system capacitor switching transient overvoltage mitigation

- 28 references

[254] GREBE, J.E., "Technologies for Transient Voltage Control During Switching of Transmission and

Distribution Capacitor Banks," Proceedings, 1995 International Conference on Power Systems Transients, Lisbon, 1995.

- Presents a summary of transient overvoltage mitigation techniques for transmission and distribution banks.

- 7 references

[255] HARNDEN, J.D., GOLDEN, F.B., MARTZLOFF, F.D., and MORRIS, W.G., "GE-MOV Varistor - The Super Alpha Varistor," Unclassified GE TIS Report 72CRD260, 1972.

- Technical version of the market announcement of the new device technology.

- Brief description of structure, principle of operation, and planned applications.

- 6 references and 26 bibliographic citations

[256] HASSE, P., Overvoltage Protection of Low-Voltage Systems. IEE Power Series, Peter Peregrinus Ltd. London, 1992. (Original German edition in 1987) Available in the U.S. from IEEE.

- Examples of causes of overvoltages and damage to electrical systems with electronic devices.

- The operation and application of proven overvoltage protection devices are considered.

- Discusses coordination with a "quenching gap" as the upstream SPD

- 244 pages, 83 references (mostly in German)

[257] HILL, R.C., KEY, T.S. and MARTZLOFF, F.D., "Characterization of Transient Voltage Suppressors from a System Compatibility Perspective," Proceedings, PQA'92 Conference, Atlanta GA, 1992.

- Background information on the family of System Compatibility test protocols.

- Reports the performance of generic surge-protective devices, not brand names.

- 21 references

[258] KEY, T.S., MARTZLOFF, F.D., NASTASI, D., and PHIPPS, K.O., "Some Enlightening Case Histories on Lightning Damage," Proceedings, $25^{\text {th }}$ International Conference on Lightning Protection, Rhodes, 2000.

- Case history on system interaction.

- Case history on damage to communications port, not power port.

- Case history on improper grounding practices.

- 6 references

[259] LAGERGREN, E.S., MARTZLOFF, F.D., PARKER, M.E., and SCHILLER, S.B., "The Effect of Repetitive Swells on Metal-Oxide Varistors," Proceedings, "92 Conference, September 1992.

- Effects of amplitude, duration, and number of swells, using change in varistor nominal voltage as criterion.

- A relatively small (less than $3 \%$ ) change in varistor nominal voltage for limited cumulative stresses.

- Failure caused by gradual aging (the $10 \%$ limit quoted by industry) was not reached in this experiment.

- Failure by overheating occurs for stresses of long-duration (seconds) temporary overvoltages.

- 8 references

[260] LAT, M.V., "Determining Temporary Overvoltage Levels for Application of Metal-Oxide Surge Arresters on Multigrounded Systems," IEEE Transactions PWRD-5, April 1990.

- Presents several calculation methods for temporary overvoltages and an evaluation of these methods.

- Defines limits of applicability of the methods.

- 8 references

[261] MANSOOR, A. and MARTZLOFF, F.D., "The Dilemma of Surge Protection vs. Overvoltage Scenarios: Implications for Low-Voltage Surge-Protective Devices," Proceedings, 8th International Conference on Harmonics and Power Quality, Oct 14-16, 1998, Athens, Greece.

- Three examples of temporary overvoltage conditions that can produce failure of SPDs.

- The significance of available fault current and the need for more explicit standards.

- 17 references

[262] MANSOOR, A., MARTZLOFF, F.D., and PHIPPS, K., "Gapped Arresters Revisited: A solution to Cascade Coordination," IEEE Transactions PWRD-13, No.4, December 1998.

- Demonstrates the principle of a coordination scheme compatible with downstream SPDs having lower limiting voltage than the SPD at the service entrance.

- 23 references 
[263] MARTZLOFF, F.D., Surge Suppression in a Typical Home Wiring System," Declassified GE TIS Report $63 G L 97,1963$.

- Injection of surges and their mitigation in a residential power system.

- Examples of suppression achieved by selenium cells before the advent of metal-oxide varistors.

- 2 references

[264] MARTZLOFF, F.D., "Evaluation of Commercial Surge Suppressors," Declassified GE TIS Report 67C-067, March 1967.

- Performance of nine commercial SPDs available before the advent of metal-oxide varistors

- Tests include voltage-switching devices and voltage-limiting devices.

[265] MARTZLOFF, F.D., "Surge Voltage Suppression in Residential Power Circuits," Unclassified GE TIS Report 76CRD092, 1976.

- Performance of mid-seventies vintage of service entrance SPD and simple MOV plug-in SPD.

- Introduction of the concept of cascade coordination achieved by the inductance of wiring.

- 4 references

[266] MARTZLOFF, F.D., "Transient Overvoltage Protection: The Implications of New Techniques," Proceedings, $4^{\text {th }}$ Symposium on Electromagnetic Compatibility, Zurich, 1981.

- A glimpse at typical protective devices available in North America and Europe in the early 80's.

- Degradation of performance resulting from improper installation techniques.

- 10 references

[267] MARTZLOFF, F.D., "Matching Surge Protective Devices to their Environment," IEEE Transactions IA-21. No. 1, January/February 1985.

- Durability assessment of metal-oxide varistors based on manufacturer's published "Pulsed lifetime ratings" and the IEEE 587 Guide on surge voltages.

- Performance and degradation of fuses subjected to repetitive surge currents.

- 10 references

[268] MARTZLOFF, F.D., "The Protection of Computer and Electronic Systems Against Power Supply and Data Line Disturbances," Unclassified GE TIS Report 85CRD084, July 1985.

- Summary of personal observations and experience on the subject circa 1985.

- Last Martzloff publication under the GE Logo.

- 39 references

[269] MARTZLOFF, F.D., "Varistor Versus Environment: Winning the Rematch," IEEE Transactions PWRD-1, No. 2, April 1986.

- Staged tests of capacitor switching on remote MV side produces ring waves on low-voltage load.

- Coordination between $3 \mathrm{kV}$ and $480 \mathrm{~V}$ varistor-based SPDs.

- 5 references, 1 discussion

[270] MARTZLOFF, F.D. and LEVINSON, L.M., "Surge Protective Devices," Chapter 5 in book Electronic Ceramics, Marcel Dekker, 1988.

- Occurrence, characteristics, and mitigation of surges.

- Varistor microstructure, conduction, and applications.

- 30 references

[271] MARTZLOFF, F.D. and LEEDY, T.F., "Selecting Varistor Clamping Voltage: Lower is Not Better !" Proceedings, $8^{\text {th }}$ International Zürich Symposium, on Electromagnetic Compatibility, 1989.

- Experimental and computed evaluation of heating effects from repetitive swells applied to MOVs.

- Four mechanisms are describe that can lead to premature failure.

- 11 references

[272] MARTZLOFF, F.D. and LEEDY, T.F., "A Glimpse at Long-term Effects of Momentary Overvoltages on ZincOxide Varistors," Transactions Ceramics Society, Vol 3, October 1989.

- Overview on the issue of ageing metal-oxide varistors subjected to repetitive momentary overvoltages ("swells").

- Computations of temperature rise in the varistor body during a swell.

- Preliminary experiments on ageing (see later experiments under [259] Lagergren et al., 1992).

- 5 references

[273] MARTZLOFF, F.D., "Protecting Computer Systems Against Power Transients," IEEE Spectrum, April 1990.

- Brief review of the origin of transients.

- Explanation of and remedy for interaction between power port and communications port. 
[274] MARTZLOFF, F.D., "Diverting Surges to Ground: Expectations vs. Reality," Proceedings, Open Forum on Surge Protection Application, NISTIR-4654, August 1991.

- Comparison of the performance of filter-type vs. voltage-limiting type surge-protective devices.

- Experimental demonstration of voltages induced in branch circuit conductors by the flow of surge currents diverted by the action of the two types of SPDs.

- 9 references

[275] MARTZLOFF, F.D. and SAMOTYJ, M., "An Important Link in Whole-house Protection: Surge Reference Equalizers," Proceedings, 10 International Zürich Symposium on Electromagnetic Compatibility, 1993.

- Explains the problem of interactions between power and comm unications systems during surge events.

- Describes the concept of a surge reference equalizer as possible remedy.

- 5 references

[276] MARTZLOFF, F.D., "Surges Happen! - How to protect the appliances in your home," Special Publication 960-6, National Institute of Standards and Technology, May 2001.

- Consumer-oriented tutorial on the origins of surges and ways to mitigate them.

- Questions and answers, installation hints.

- 20 pages

[277] McGRANAGHAN, M., REID, W.E., LAW, S., and GRESHAM, D., "Overvoltage Protection of Shunt Capacitor Banks Using MOV Arresters," IEEE Transactions PAS-104, No.8, August 1984.

- Evaluation of MOV surge arresters for the overvoltage protection of shunt capacitor banks, including impact of lightning and switching transients.

- 10 references, 4 discussions

[278] McGRANAGHAN, M.F., ZAVADIL, R.M., HENSLEY, G., SINGH, T., and SAMOTYJ, M., "Impact of Utility Switched Capacitors on Customer Systems - Magnification at LV Capacitors," IEEE Transactions PWRD-7, No.2, April 1992.

- Parametric analysis of the effects of capacitor switching.

- Shows high stresses on SPDs.

- Mitigation at the switched capacitor.

- 5 references

[279] MIKHAIL, S. and McGRANAGHAN, M., "Evaluation of Switching Concerns Associated with 345 kV Shunt Capacitor Applications," IEEE Transactions PAS-106, No.4, 1986.

- Results of a Transient Network Analyzer study of switching 2500 MVAR 345 kV capacitor banks.

- Normal energizing, voltage magnification, phase-to-phase transients, inrush, outrush, and restrike events

- 14 references, 2 discussions

[280] SCUKA, V., "EMI Control in Low-Voltage Power Installations." Proceedings, $7^{\text {th }}$ International Zürich Symposium on Electromagnetic Compatibility, 1987.

- Laboratory measurements of propagation parameters on typical wiring practices

- Comparisons between gap-type and varistor SPDs.

- Recommendation on grounding practices and building construction.

- 8 references

[281] SMITH, S.B. and STANDLER, R.B., "The Effects of Surges on Electronic Appliances," IEEE Transactions PWRD-7, No.3, July 1992.

- A total of 16 different clocks, television receivers, microwave ovens, and dc power supplies were subjected to three different surge waveforms with amplitudes between $0.5 \mathrm{kV}$ and $6 \mathrm{kV}$.

- Switching power supplies and television receivers were damaged with surges between $4 \mathrm{kV}$ and $6 \mathrm{kV}$.

- Three of five models of digital locks were upset (temporary malfunction) with surges between $1.5 \mathrm{kV}$ and $6 \mathrm{kV}$.

- 19 references

[282] STANDLER, R.B., "Protection of Small Computers from Disturbances on the Mains," Conference Record of the 1988 Industry Applications Society Annual Meeting.

- Simple rules for the protection of small computer system from disturbances on the mains.

- If a system operation is critical, the combination of varistors, line conditioner, and a standby UPS is recommended.

- Provides historical data on author's computer protection experience.

- 12 references 
[283] STANDLER, R.B., "Use of Low-Pass Filters to Protect Equipment from Transient Overvoltages on the Mains," Conference Record. Industrial and Commercial Power Systems Technical Conference 1988

- Review of the design of commercial low-pass filter modules for equipment connected to the LV supply mains.

- Discusses problems of using these filters to protect electronic equipment from damage or upset by high-voltage transients on the mains.

- 12 references

[284] STANDLER, R.B., "Use of a Metal-Oxide Varistor with a Series Spark Gap Across the Mains," Proceedings, 1990 International Symposium on Electromagnetic Compatibility Symposium, 1990.

- Discusses the use of a series spark gap with a metal oxide varistor to achieve both a small clamping voltage and a long life time for the surge-protective circuit.

- Extinguishing follow current in the gap and attenuating the remnant that propagates downstream prior to the conduction of the spark gap are discussed in detail.

- 5 references

[285] STANDLER, R.B., "Design and Performance of Surge Suppressors," Proceedings, IEEE International Symposium on Electromagnetic Compatibility, 1993.

- Tests on more than two dozen different models of commercially available surge suppressors during 1987-1990 showed that some types of suppressors perform much better than others.

- The manufacturer's specifications and UL clamping voltage rating are often not consistent with laboratory measurements.

- 25 references

[286] STRINGFELLOW, M.F., "Fire Hazard of Surge Suppressors," Proceedings, Power Quality Conference, Anaheim CA, September 1992.

- Suppressors removed from service throughout the U.S. and Canada, contrary to popular myth, field data shows that surge suppressors containing metal oxide varistors do not degrade in service.

- All suppressors are, however, exposed to rare incidents of severe power-frequency overvoltage caused by power-line accidents, such as broken neutral conductors, which can cause suppressors to overheat internally.

- Products equipped with overcurrent fuses or magnetic circuit breakers might catch fire in rare cases. This is true for those having both plastic and metal housings and components rated for both $130 \mathrm{~V}$ and $150 \mathrm{~V}$.

- A fire hazard test is proposed to be added to safety agency tests for surge suppressors and similar products.

- 3 references 
Page 34 


\section{Coordination of cascaded SPDs}

[287] GOEDDE, G.L., MARZ, M.B., and HENRY, D.C., "Coordinating Lightning Stroke Protection From the Utility System to Load Devices," Proceedings, Second International Power Quality/ESD Conference, October 1990.

- Describes secondary surge phenomena and the importance of transformer secondary circuit protection coordination to both utilities and end users.

- An effective MOV protection coordination scheme is described and recommended

- Multiple grounds at different potentials, especially under lightning surge conditions, prevent distribution transformer primary arresters from protecting secondary circuits.

- 13 references

[288] HASSE, P., ZAHLMANN, P., WIESINGER, J., and ZISCHANK, W., "Principle for an Advanced Coordination of Surge-protective Devices in Low-voltage Systems," Proceedings, $22^{\text {nd }}$ International Conference on Lightning Protection, Budapest, 1994.

- Proposes a scheme where the performance of SPDs for any waveform is converted to an equivalent configuration referred to the performance under the Combination Wave.

- 7 references

[289] HOSTFET, O.T., HERVLAND, T., NANSEN, B., and HUSE, J., "Coordination of Surge Protective Devices in Power Supply Systems: Needs for Secondary Protection," Proceedings, 21" International Conference on Lightning Protection, Berlin, September 1992.

- On the basis of observed failures on secondary surge protection devices, theoretical and experimental investigations are performed in order to clarify the need for such protection including the sharing of energy stresses in relation to the primary surge protection system.

- The higher energy stresses will generally occur on the device with the lowest limiting voltage. Therefore, the protection level for the secondary protection should be selected higher than for the primary protection.

- 5 references

[290] LAI, J.S., "Performance Criteria for Cascading Surge-Protective Devices," Proceedings, Open Forum on Surge Protection Application, NISTIR-4654, August 1991.

- Voltage limiting level of cascaded devices, their separation distance, and surge waveform are used as parameters to compute the energy deposited in the devices.

- Experimental verification shows reasonable agreement between simulation and experiment.

- Contains details of the data base used for the Lai \& Martzloff IEEE Transactions IA-24 1993 paper [291].

- 10 references

[291] LAI, J.S. and MARTZLOFF, F.D., "Coordinating Cascaded Surge-Protection Devices: High-Low versus LowHigh," IEEE Transactions IA-24, No.4, July/August 1993. (First publication, Conference Record, IEEE IAS Annual Meeting September 1991.)

- Computations and experiments showing the effect of line length and impinging surge waveform on sharing energy between service entrance arrester and SPD inside building.

- While the $8 / 20$ us waveform can still result in a contribution from both devices to sharing the energy, the $10 / 1000 \mu s$ waveform does not produce any inductive separation of the devices past the rise time, so that energy is equally shared between devices of equal rating.

- 11 references

[292] MANSOOR, A., MARTZLOFF, F.D., and PHIPPS, K., "Gapped Arresters Revisited: A Solution to Cascade Coordination," IEEE Transactions PWRD-13, No.4, December 1998.

- Demonstrates the principle of a coordination scheme compatible with downstream SPDs having lower limiting voltage than the SPD at the service entrance.

- 23 references

[293] MARTZLOFF, F.D., "Surge Voltage Suppression in Residential Power Circuits," Unclassified GE TIS Report 76CRD092, 1976

- Performance of mid-seventies vintage of service entrance SPD and simple MOV plug-in SPD.

- Introduction of the concept of cascade coordination achieved by the inductance of wiring.

- 4 references 
[294] MARTZLOFF, F.D., "Coordination of SPDs in Low-Voltage AC Power Circuits," IEEE Transactions PAS-99, No. 1, Jan/Feb 1980.

- Coordination between voltage-switching and voltage-limiting SPDs.

- Coupling between equipment grounding conductor and phase wires.

- Where an unidirectional current is injected into the ground system only, the response of the system is an oscillating voltage involving the phase conductors.

- Without substantial connected loads in the system, the open-circuit surges appearing at the service entrance propagate along the branch circuits with very little attenuation.

- 7 references

[295] MARTZLOFF, F.D. and LAI, J.S., "Cascading Surge-Protective Devices: Coordination versus the IEC 664 Staircase," Proceedings, PQA '91 Conference.

- Coordination of cascaded devices can be achieved under various combinations of parameters, but some combinations might leave the smaller device subjected to the highest stress.

- Significant parameters in achieving successful coordination involve three factors, over which the occupant of the premises has no control: the relative limiting voltages of the two devices, their separation distance, and the prevailing waveforms for impinging surges.

- 13 references

[296] MARTZLOFF, F.D. and LAI, J.S., "Cascading Surge-Protective Devices: Options for Effective Implementation," Proceedings, PQA '92 Conference, September 1992.

- Implications of the situation resulting from the present uncoordinated application of devices with low limiting voltage at the end of branch circuits and devices with higher limiting voltage at the service entrance.

- The reality of having many millions of $130-\mathrm{V}$ rated varistors installed on $120-\mathrm{V}$ systems makes the ideal scenario of a well-coordinated cascade difficult or perhaps unattainable in the near future.

- As a compromise, a cascade with equal voltage ratings for the arrester and the suppressor can offer successful coordination, if the impinging surges are presumed to be relatively short.

- Tolerances on device characteristics might make the compromise ineffective.

- Bibliography with 32 citations

[297] MARZ, M.B. and MENDIS, S.R., "Protecting Load Devices from the Effects of Low-Side Surges," Proceedings, IEEE/ICPS Conference, May 1992.

- Utilities are becoming aware of the low-side surge phenomenon and are applying secondary arresters to protect their distribution transformers. This practice can increase the voltage stress at the customer service entrance.

- If any ground paths exist on the customer side of the service entrance, these surges can penetrate further in to the customer's system.

- Damage caused by low-side surges can be avoided if properly coordinated arresters are installed at the transformer secondary, service entrance, and load device.

- 15 references

[298] STANDLER, R.B., "Coordination of Surge Arresters and Suppressors for Use on Low-Voltage Mains," Proceedings, $g^{\text {h }}$ International Zürich Symposium on Electromagnetic Compatibility, 1991.

- Results of both a theoretical analysis and laboratory experiments are reported on sharing of current between an arrester at the service entrance and a suppressor at receptacles during surges.

- Shows that it is better to design the arrester with a smaller conduction voltage than the suppressor, in order to obtain better coordination, better electromagnetic compatibility, and lower cost.

- Computations were made with only resistance of wire between cascaded devices, no inductance.

- 9 references

[299] STRINGFELLOW, M.F. and STONELY, B.T., "Coordination of Surge Suppressors in Low-Voltage AC Power Circuits," Proceedings, Forum on Surge Protection Application, NISTIR-4657, August 1991.

- Experiments showing the effect of line length and impinging surge waveform on sharing energy between service entrance arrester and surge suppressor inside building.

- Metal-oxide varistors were applied at three points on the system. These were at the service entrance, at the distribution panel and at the load.

- Removal of protection at either load or distribution panel resulted in unacceptably large oscillatory voltages. Best load protection was achieved with MOVs in all three locations.

- 4 references

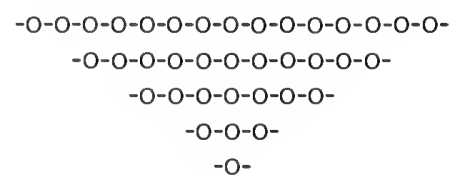




\section{Authors Index}

ACKERMANN, G.

AIEE Committee Report

ALLEN, G.W.

ALTMAIER, $\mathrm{H}$.

ANDERSON, L.M.

ANDERSON, R.B

ASPNES, J.D

AURIOL, P.

$\mathrm{BACHL}, \mathrm{H}$.

BACHMAN, L.

BARDO, E.A.

BARKER, P.P.

BARTKOWIAK, M.

BEJLERI, M

BELHOMME, R. . ...... 59

BENDA, S. . . . . . . 234

BERGER, K.

BERLANDIS, J.P.

BERNSTEIN, R.

BIRD, A.O.

BIRKL, J.

BIRRELL, D.

BLACK, S.

BOBERG, $S$.

BODLE, D.W

BOEHNE, E.W

BOUTET, F.

BOWES, K.B

BRASKICH, B.J.

BROMS, $M$.

BULL, J.H

BUSCHKE, H.A.

CANNOVA, S.F

CHAN, J.S.

CHOWDHURI, P.

CIANOS, N.

CIGRE

COMBER, M.G.

CROUCH, K.E.

CUMMINS, K.L.

DARVENIZA, M.

DAVIDSON, R.

DAVIES, D.W.

DE LA ROSA, F.

DEAM, D.R.

DESROSIERS, D.
50,51

52

53,162

106

24

54,60

52

150

. 25

53

67

54

26

44

60

99

202, 242

235

107, 167

236

30

105

61,204

. 62

152

24

93

105

63,163

164

64

81

65

66

108,205

. 26

109,131

67, 165

68,248

238

197

198

240

59
DORR, D.S.

69

DUGAN, R.C

$74,110,111,112$, $113,114,115,208,250,251$

ECHIGO, $\mathrm{H}$.

92

EHRLER, J

109

EPRI

110

ERIKSSON, A.J.

51,111

EVANS. B.W.

52

EYBERT-BERARD, A.

. 99

FENIMORE, C.

27,28

FERNANDEZ, M.I. 58, 70, 71, 99 ,

119, 144, 145, 151, 202, 209, 242

FISHER, F.A.

$37,166,185$

$210,211,220$

FORTI, M.M.

$187,188,189$

GAGNON, C

59

GAIBROIS, G.L.

72, 161

GALE, L.J.

160

GAUPER, H.A.

134

GHAZI, A.J

61,204

GOEDBLOED, J.J

GOEDDE,

$29,74,113,114$

$251,252,287$

GOLDE, R.H.

202

GOLDEN, C.

193,232

GOLDEN, F.B

242

GOLDSTEIN, M.

75

GRADY, W.W

141

GRÄF, $T$. 149

GR.AF, W.

49

GREBE, T. 76, 120, 121, 253, 254

GREENWOOD, A. . ..... 203

GRESHAM, D 261

GRUZS, T.M. . . . 204, 214, 216

GUERRIERI, S. . . ...... 99

GULLBERG, M. ....... 53

GUMLEY, R. 230

HAHN, G.J.

77,86

HAIRABEDIAN, B.

78

HARDIN, K.B.

148

HARNDEN, J.D.

242

HARTANA, R.

HARUKI, H.

74

HASLER, R. 79

HASSE, P.

107, 167, 215,

$243,256,288$
HENDERSON R.W.

HENRY, D.C

272

HENSLEY, G

$114,115,264$

HERVLAND, T.

289

HILL, R.C.

244

HISCOX, W.L.

HOSTFET, O.T. . . . . . 289

HUDASCH, M. ....... 50

HUGHES, M.B. . . . . . . 81

HUSE, J. . . . . . . . . 289

IEEE Committee Report . . . 206

JOHNSON, I.B. . . . . . . 116

JOHNSON, K. . . . . . 72

KATOH, J. . . . . . . . . 79

KEY, T.S.

$30,82,124,168$

$189,217,218,257,258$

KIMATA, R. ......... 79

KIMBARK, E.W. . ...... 118

KNABE, E.S. . . . . . . 238

KOJOVIC, Lj.A. . . . . . 29, 252

KREISS, D.G. . ...... 170

KRIDER, E.P. . ....... 165

KRÖNINGER, $H . \ldots \ldots \ldots 60$

KÜTTNER, H. . ........ 109

KVALTINE, D.J. . ....... 54

LAGADEC, R. . . . . . . 80

LAGERGREN, E.S. . . . . . 246

LAI, J.S. . . . 290, 291, 295, 296

LAW, S. . . . . . . . . 261

LEEDY, T.F. . 137, 227, 271, 272

LEGATE, A.C. . . . . . 118

LENZ, J.E. . . . . . . . . . 83

LEROY, J. . . . . . . . . 95

LEVINSON, L.M. . . . . . . 255

LIN, Y.T. . . . . . 127, 143

LINDES, G. . . . . . . . 171

LOW, S.S. . ......... 62

MacGORMAN, D.R. ...... 84

MACl, S.S. . . . ..... 179

MACIELA, F. ........ 31

MADZAREVIC, $V . \ldots \ldots \ldots 147$

MAHAN, G.D. . ....... 26

MAIER, M.W. ........ 84

MALONE, M.D. . ....... 165

MANCAO, R.T. . ....... 54 
MANSOOR, A. $\quad 32,33,34,35$, $36,128,129,141,169$, $171,172,261,262,292$

MARKEL, L.C. 173

MARTZLOFF, F.D. $†$

MARZ, M.B. 287,297

MASHIKIAN, M.S. 72

MASTER, M.J 143

MATA, C.T. $58,79,119$ $144,145,151$

MAY, J. 30,209

MCEACHERN, A. 89,186 MCGRANAGHAN, M.F. 121, 122 , $146,277,278,279$

MEAL, D.V. . ....... 111

MEHTA, H. ......... 173

MEISSEN, W. . ..... 42, 90

MELHORN, C.J. . . . . . . 173

MELLITT, B. ........... 91

MENDIS, S.R. . ....... 297

MERRITT, R.P. . . . . . . . 55

MICHAUD, J. .......... 152

MIKHAIL, S. ....... 146, 279

MILLANTA, L.M.. . . . 187, 188, 189

MINEGISHI, S. . ........ 92

MORGAN, J.D. ......... 161

MORRIS, W.G. ......... 242

MURPHY, M.J. ........ 67

NAKRA, H. . ......... 59

NANEVICZ, J.E. ........ 49

NANSEN, B. . . . . . . 289

NASTASI, D. . . . 25, 32, 219, 258

NAVE, M.J. .......... 190

NETHERCOT, M.A. . . . . . 63

NIEBUHR, W.D. . . . . . . 147

NIGGLI, M.R. . . . . . . 147

NUCCI, C.A. . . . . 9 99, 207

OAENEAL, B. ........ 160

ODENBERG, R. ........ 93

ORVILLE, R.E. . . . . . . . 94

PARKER, M.E. . ....... 246

PARRISH, D.E. ........ 57

PAUL, C.R. . ........ 148

PELLEGRINI, G. . . . . 40 40, 182

PELLETIN, J. ........... 95

† Martzloff citation numbers not listed in this index
PELZ, D. ..........106 PFEIFFER, $W$ 96,149

PHIPPS, K.O. $36,141,172$, $219,258,262,292$

PIERCE, E.T. . . . . . . 66 PIFER, A.E. .......... 67

PLAMONDON, M. ...... 59 PODGORSKI, A.S. . . . . . 222 POPOLANSKY, F. ........ 97

PROCHAKZKA, F. . . . . . . 97 PYLE, R.B.

67,94

RACHIDI, F. 99

RAKOTOMALALA, A. ..... 150 RAKOV, V.A. $\quad 58,70,71,98,99$, $119,144,145,151,202$ $207,209,233,234,242$

RAMBO, K.J. . . 58, 70, 119, 144 , $151,202,209,242$

REID, W.E. . . . . . . . 261

RHOADES, W.T. . . 100, 235, 236 237238,239

RICHMAN, P. . 43, 191, 192, 193 ROCAMORA, R.G. . . . . . . 147

ROCHEREAU, H. . . . . . . 152

ROUSSEAU, A. . 44, 150, 153, 240

ROWE, L.D.. . . . . . . . . 74, 14

ROY, D. .............. 153

RUBINSTEIN, M. ......... 99

RUST, W.D. . . . . . . . . . 84

SABIN, D.D. . . . . . . . 101

SACHS, H. .......... 53

SAMOTYJ, M. $114,115,261,264$

SATO,R. .............. 92

SCHEIBE, K. . . . . . 51, 106

SCHEUERER, F. ........ 96

SCHILLER, S.B. . . . . . . 246

SCHLAMP, M. .......... 97

SCHWETZ, S. ......... 50

SEGALL, D. . . . . . . . . 53

SENKO, G. ........... 194

SHAKARJIAN, D.R. . . . . 195

SILVA, R.F. .......... 116

SINGH, T. ......114, 115, 264

SKLIUTAS, J. . . . . . . . 74

SCUKA, V. ........ 154, 280

SMITH, S.B.

45,281
SMITH, S.D. …110, 112, 250 SPERANZA, P.D. . . . . 75, 102 STANDLER, R.B. . 45, 46, 47, 48, $103,127,13,155,156,157$, 158, 195, 196, 197, 198, 199, $200,201,206,241,246,281$, $282,283,284,285,298$

STAPLETON, M. 70, 119, 144, 151 STIMPER, K. 50,51 STONELY, B.T. . . . . . 159299 STRICKLER, F. ........ 53 STRINGFELLOW, M.F. 118,158 , 286, 299

SUNAGA, M. ........ 79

SUNDE, E.D. . . . . . . . 104

SUTIL, R.R. . . . . . . . 151

SYED, M. . . . . . . 61, 204

THOTTAPPILLIL, R. ...... 99

TRUEBLOOD, H.M. . . . . . 104

TRUSSELL, H.G. . . . . . . 160

UMAN, M.A. . 58, 68, 70,71, 98 , $99,119,127,143,144$, $145,151,202,209,242$

VANCE, E.F. . . . . . . . 49

VANNOY, D. ......... 171

VAUGHT, T.W. . . . . 202, 242

VINES, R.M. ........ 160

WALLING, R. . . . . . . . 74

WARSMANN, P. . . . . . 153

WERNSTRÖM, H. . . . . . 105

WIESINGER, J. . . 203, 243, 288

WIITANEN, D.O. ....... 161

WILLIAMS, S.R. . . . . . 173

WILSON, P.F. . . . . . . 136

WILSON, D.D.. . ....... 116

WITT, R. ........... 30

WOODSIDE, R.L. . . . . 61, 204

WOODWORTH, J.J. ...... 29

XEMARD, A. ......... 152

YTURRALDE, W.E. . . . . . 147

ZAHLMANN, P. . . . . 104, 273

ZAVADIL, R.M. . . . . 115, 264

ZEDDAM, A. ......... 152

ZISCHANK, W. ....... 288 



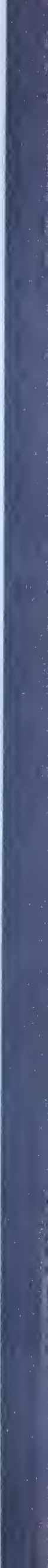

